\title{
Diversity of insect galls from Mato Grosso State, Brazil: Cerrado
}

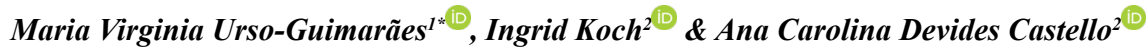 \\ ${ }^{1}$ Universidade Federal de São Carlos, Departamento de Biologia, Sorocaba, SP, Brasil. \\ ${ }^{2}$ Universidade Estadual de Campinas, Departamento de Biologia Vegetal, Campinas, SP, Brasil. \\ *Corresponding author: mvirginiaurso@gmail.com
}

\begin{abstract}
URSO-GUIMARÃES, M.V., KOCH, I., CASTELLO, A.C.D. Diversity of insect galls from Mato Grosso State, Brazil: Cerrado. Biota Neotropica 21(3): e20211189. https://doi.org/ 10.1590/1676-0611-BN-2021-1189
\end{abstract}

\begin{abstract}
The Midwest region of Brazil possesses large areas dominated by the Cerrado that is poorly known concerning insect gall and their interactions. In this study, we inventory the gall morphology, host plants, and the gall makers from Parque Nacional da Chapada dos Guimarães, Mato Grosso State, in areas of natural vegetation from Cerrado, for the first time. Samplings occurred in two expeditions, July 2012 and January 2013. We characterized 295 morphotypes of insect galls in 140 host plant species, with 89 gall makers; the richest family in host plants was Fabaceae (16.7\%), and the species was Protium heptaphyllum (Aubl.) Marchand (Burseraceae, 3.7\%). Parque Nacional da Chapada dos Guimarães is the richest Brazilian cerrado area in gall morphotypes (295) and the second in average morphotypes/host plant species (2.1). Additionally, six genera and 38 species are new records as host plants; two of them, Bernardia similis Pax and K.Hoffm and Ormosia macrophylla Benth., are new occurrences for Mato Grosso State, and other two, Vochysia petraea Warm. and Talisia subalbens (Mart.) Radlk. are listed in the Red List of Threatened Species IUCN. This inventory data represents a testimony of insect-plant interactions in a Brazilian Cerrado area that was consumed by an unprecedented fire in the dry season of 2020.

Keywords: Biodiversity; Brazilian savannah; gall makers; Neotropical region; insect-plant interaction.
\end{abstract}

\section{Diversidade de galhas de insetos do Estado do Mato Grosso, Brasil: Cerrado}

Resumo: A região Centro-Oeste do Brasil possui grandes áreas dominadas pelo Cerrado nas quais insetos e suas interações são pouco conhecidos. Neste estudo, fizemos o inventário de galhas, plantas hospedeiras e galhadores do Parque Nacional da Chapada dos Guimarães, Mato Grosso, uma área de vegetação natural de Cerrado. As amostragens foram realizadas em duas expedições, em julho de 2012 e janeiro de 2013. Caracterizamos 295 morfotipos de galhas de insetos em 140 espécies de plantas hospedeiras; com identificação de 89 galhadores; a família de plantas com maior número de espécies hospedeiras de galhas foi Fabaceae $(16,7 \%)$ e a espécie com maior número de galhas, Protium heptaphyllum (Aubl.) Marchand (Burseraceae, 3,7\%). Esta é a área mais rica em morfotipos de galhas do cerrado brasileiro (295) e a segunda na média de morfotipos/espécie de planta hospedeira $(2,1)$. Além disso, seis gêneros e 38 espécies são registros novos de ocorrência de plantas hospedeiras para galhas de insetos; duas delas, Bernardia similis Pax and K.Hoffm and Ormosia macrophylla Benth., são registros novos para o Estado do Mato Grosso e outras duas, Vochysia petraea Warm. and Talisia subalbens (Mart.) Radlk. estão listadas na Lista Vermelha de Espécies Ameaçadas IUCN. Os dados desse inventário representam um testemunho das interações inseto-planta para o Cerrado no Brasil, em uma área que foi consumida por um incêndio sem precedentes na estação seca de 2020.

Palavras-chave: Biodiversidade; galhadores; interação inseto-planta; região Neotropical; savana brasileira. 


\section{Introduction}

Insect-plant interactions are among the most interesting subjects in science, and inventories of the association between host plants and insect gall makers are among the trend topics of studies in the scientific community dedicated to this theme in Brazil. In the last 30 years, more than 50 inventories focusing on insect galls were performed in all Brazilian biomes, with predominance in Atlantic Forest and Cerrado, with 23 and 22 inventories, respectively (Araújo et al. 2019).

The Cerrado from central Brazil harbors the most significant extent of savanna in the Neotropics (Bueno et al. 2018), and it is facing alarming record rates of deforestation (Russo et al. 2018), massively in the Southeast region ( $60 \%$ ), especially in the State of Minas Gerais ( $\sim 33 \%)$. Depending on its geographic distribution, it is affected by innumerous environmental conditions, like soil fertility, water availability, and temperature. Regarding the composition of its phytophysiognomies, Cerrado is severely influenced by adjacent biomes (Bueno et al. 2018). The phytophysiognomies distributed in the states of Minas Gerais, São Paulo, Bahia, Piauí, Maranhão, and the eastern region of Tocantins and Goiás are influenced by the conditions of the Atlantic Forest and Caatinga biome. In contrast, the composition of the vegetation distributed in the States of Mato Grosso do Sul, Mato Grosso, western Goiás, and Tocantins are influenced by the environmental conditions of Amazon, Pantanal, and Chaco biomes. All these complexities make Cerrado the focus of many studies.

Although most of the inventories of the insect galls communities were done in the Cerrado environment, most were restricted to the States of Minas Gerais (41\%), Goiás (28\%), and Bahia (22\%) (Cintra et al. 2020), portraying more the community of active researchers around the sampled areas than the representativeness of the areas in the Cerrado biome. The Midwest region of Brazil possess large areas dominated by the Cerrado, and it is poorly known concerning gall communities, since just about $15 \%$ of all studies on insect galls were done in this region (Araújo et al. 2019, Cintra et al. 2020), and none in areas located in the state of Mato Grosso.

Cintra et al. (2020) made an important compilation from insect galls communities sampled in 32 areas of the Cerrado Biome in Minas Gerais, Goiás, Bahia, São Paulo, and Mato Grosso do Sul States. The authorsregistered host plants of 505 species, 222 genera, and 67 families. Nine species threatened of extinction: Baccharis concinna G.M.Barroso (Asteraceae), Lychnophora ramosissima Gardner (Asteraceae), and Lychnophora tomentosa (Mart. ex DC.) Sch.Bip. (Asteraceae). In this study, we characterized gall morphology, identified host plants and the gall makers from Parque Nacional da Chapada dos Guimarães, Mato Grosso State, to contribute to the increase in the knowledge about host plant species and their gall morphotypes associated with gall-inducing insects in areas of natural vegetation from Cerrado. This inventory is the first record of insect-plant interactions in a region threatened by an unprecedented fire in the dry season of 2020 (Marengo et al. 2021). In this troubling scenario, our inventory represents a testimony of insect-plant interactions consumed by the fire and increases knowledge for the insect galls communities of Cerrado.

\section{Material and Methods}

\section{Study site}

The study was conducted during the expeditions of the "Rede Temática para Estudos de Diversidade, Sistemática e Limites Distribucionais de Diptera nos Estados do Mato Grosso, Mato Grosso do Sul e Rondônia (SISBIOTA-Diptera Brazil Program, Proc. Fapesp 10/52314-0; Proc. CNPq 563256/2010-9) in the Parque Nacional da Chapada dos Guimarães (PNCG), State of Mato Grosso, Brazil (Fig. 1), which is recognized internationally as a Biosphere Reserve.

The PNCG is located in the Cerrado Biome. The climate is classified as Tropical Climate of Savana (Aw), with two well-defined seasons (hot and rainy in summer; dry and cold in winter). Two geological regions are found in the PNCG, the Cuiabana Depression, which altitude is $200-450$ $m$ and the Guimarães Plateau with altitudes $600-800$ m (MMA, 2009). The sampling areas list, including the sampled phytophysiognomies (classified after Ribeiro \& Walter 2008), are presented in Table 1.

\section{Sampling}

We made the samples in two expeditions, in July 2012 and January 2013, with an effort of 30 minutes in each point in both, except for Cachoeira das Andorinhas sampled once in July 2012 and Vale do Rio Claro sampled once in January 2013, following Price et al. (1998). We sampled along the trails' edges, and we measured each route's length to dimension the sampled area following Urso-Guimarães et al. (2017). The total sampling effort in PNCH was 5 hours. Plant branches with galls were collected, labeled, stored in plastic bags and taken to the laboratory to document the galls' morphotypes, following Araújo et al. (2021). We transferred part of the galls to plastic tubes for rearing the inducers. We identified gall makers and plant species using identification keys compared with type material, literature, and experts' help. The voucher specimens were deposited in the Universidade Federal de São Carlos: plants in the Herbarium SORO and the insect material in the Laboratório de Sistemática de Diptera.

\section{Results}

We identified in the Parque Nacional da Chapada dos Guimarães 295 morphotypes of insect galls in 140 host plant species from 84 genera and 41 families (Table 2, Figs. 2-9). On average, we found 2.1 gall morphotypes per plant species (for comparisons with other inventories in Cerrado areas, see Table 3). Three host plants are identified only at a family level, and 11 are completely unidentified. The richest plant

Table 1. Sampling localities in Parque Nacional Chapada dos Guimarães - Mato Grosso State informing phytophysiognomy, geographical coordinates of the starting points and route length.

\begin{tabular}{|c|c|c|c|}
\hline Localities & Phytophysiognomies & Geographical Coordinates & Route length \\
\hline Cachoeira das Andorinhas & Cerrado s.l. & $15^{\circ} 24^{\prime} 47.8^{\prime \prime} \mathrm{S} \& 055^{\circ} 50^{\prime} 34^{\prime \prime} \mathrm{W}$ & $174 \mathrm{~m}$ \\
\hline Vale do Eco & Campo Cerrado & $15^{\circ} 20^{\prime} 54.2^{\prime \prime} \mathrm{S} \& 055^{\circ} 47^{\prime} 59.9^{\prime \prime} \mathrm{W}$ & $149 \mathrm{~m}$ \\
\hline Vale da Benção & Gallery forest & $15^{\circ} 26^{\prime} 10^{\prime} \mathrm{S} \& 055^{\circ} 47^{\prime} 23 ” \mathrm{~W}$ & $47 \mathrm{~m}$ \\
\hline Cidade de Pedra & Cerrado rupestre & $15^{\circ} 18^{\prime} 00.4$ " S \& $055^{\circ} 50^{\prime} 26.2^{\prime \prime} \mathrm{W}$ & $37.5 \mathrm{~m}$ \\
\hline
\end{tabular}




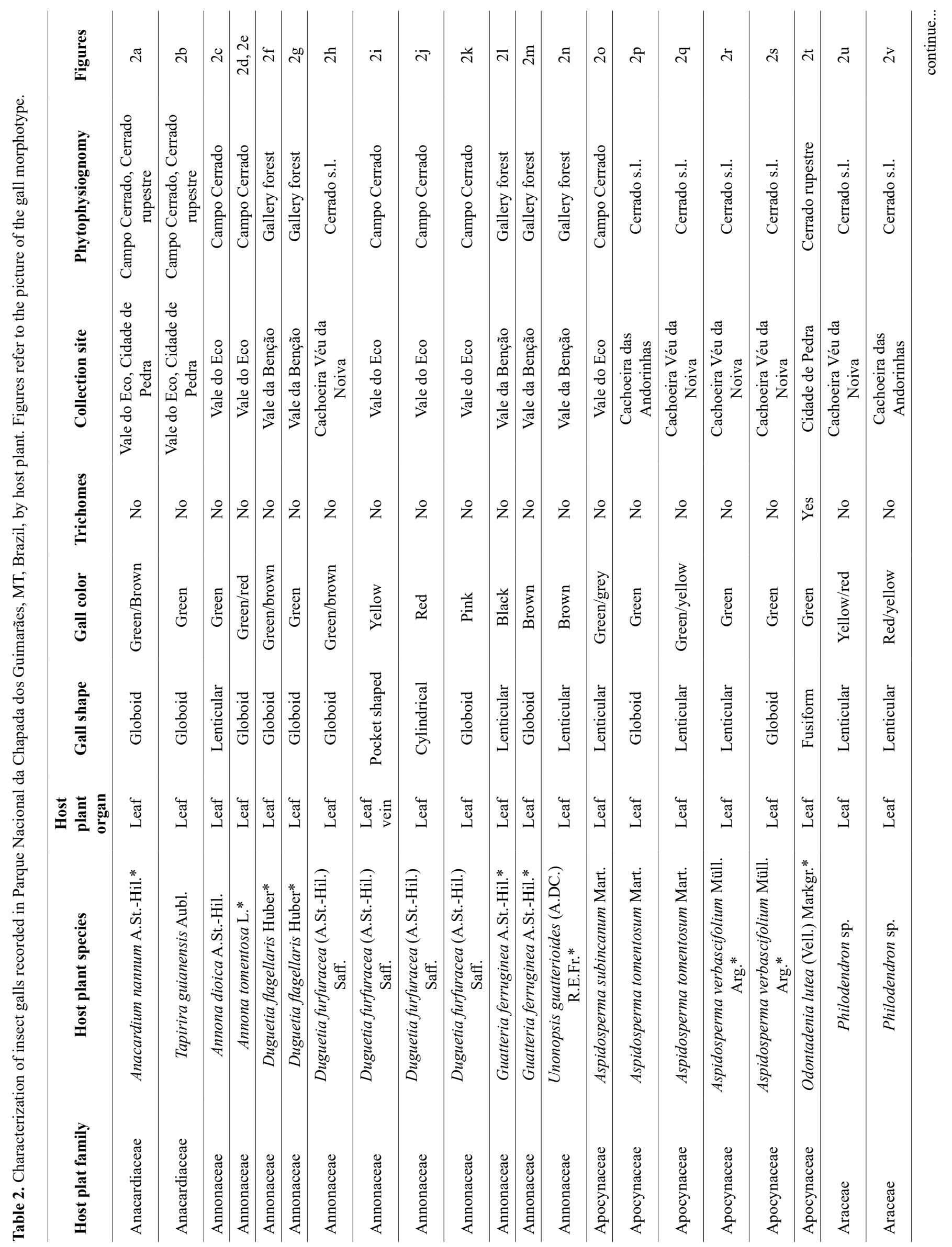




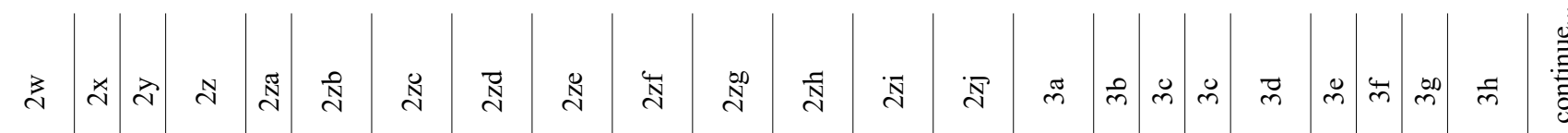

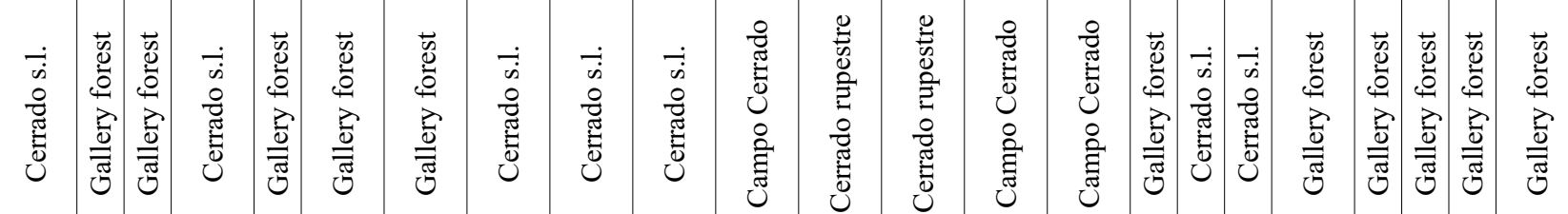

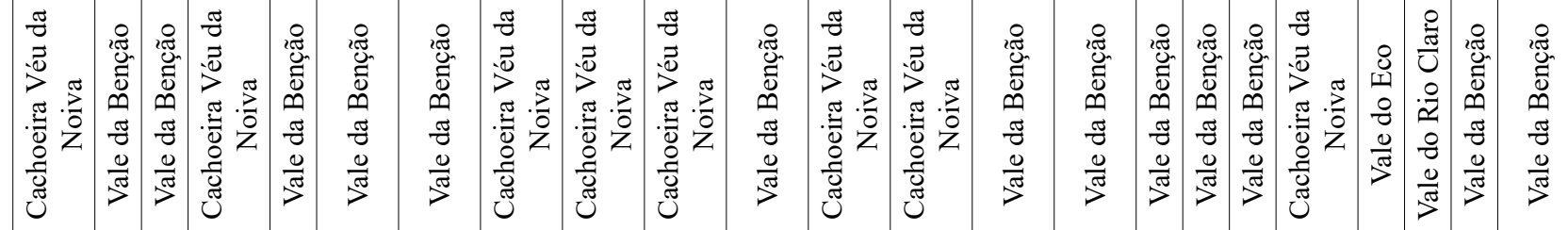

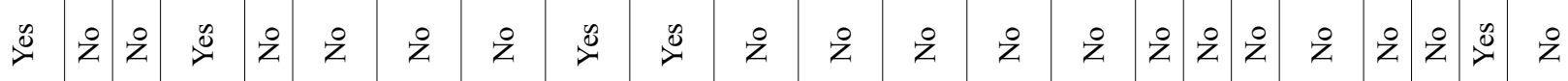

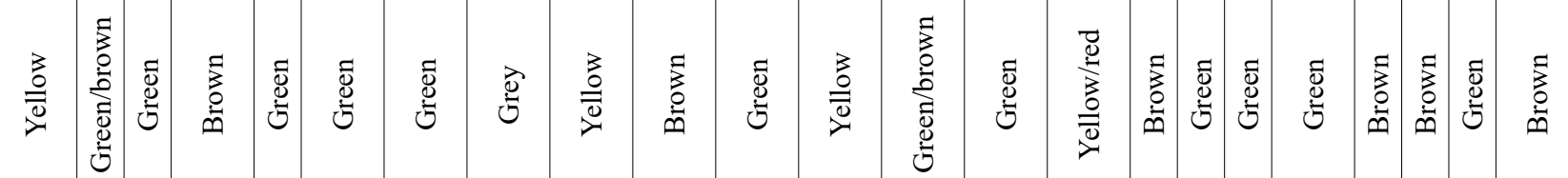

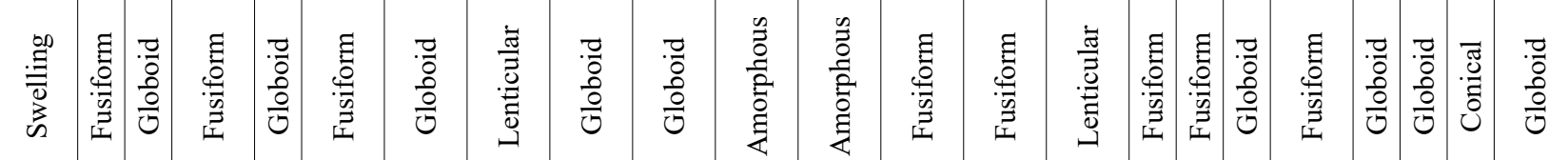

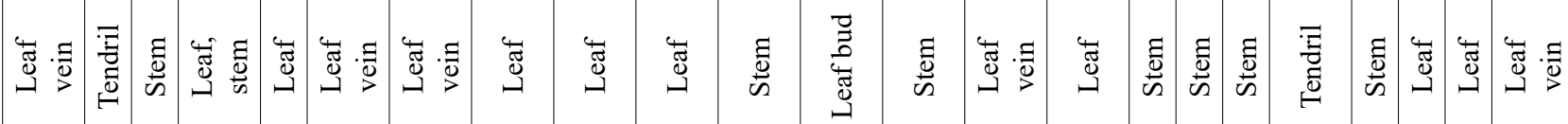

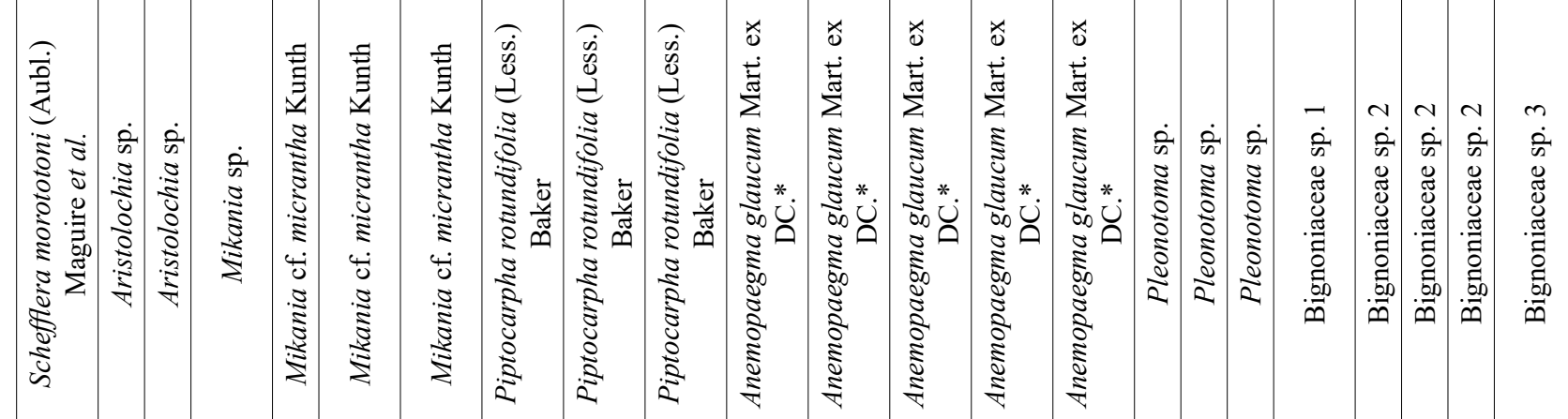

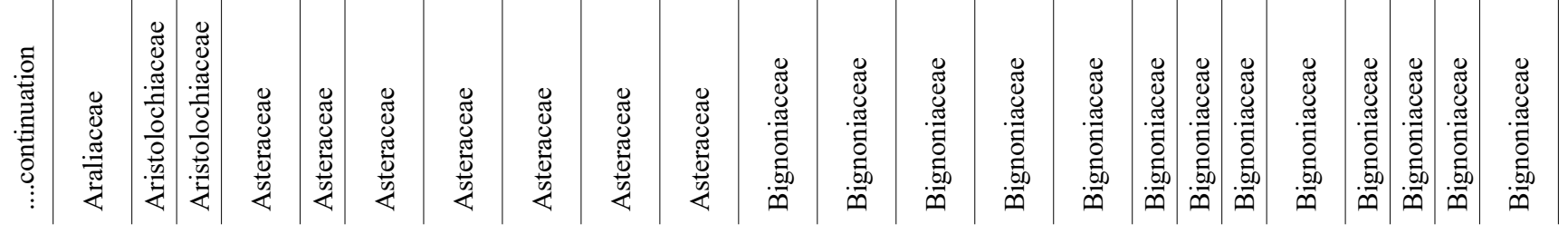




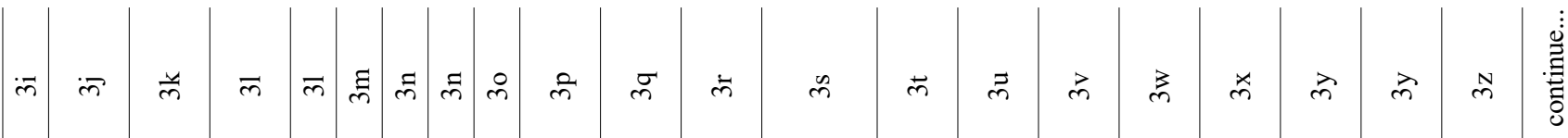

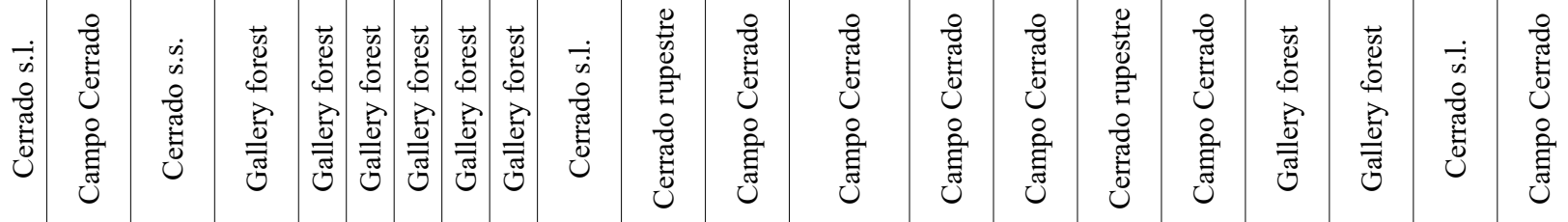

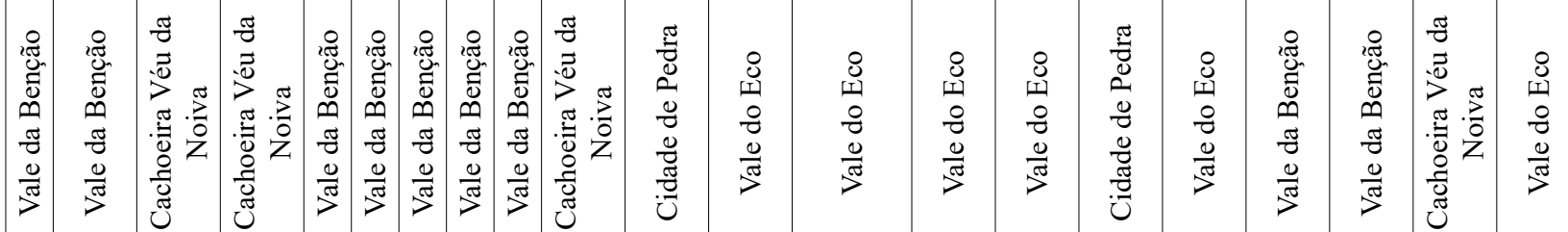

ż ż

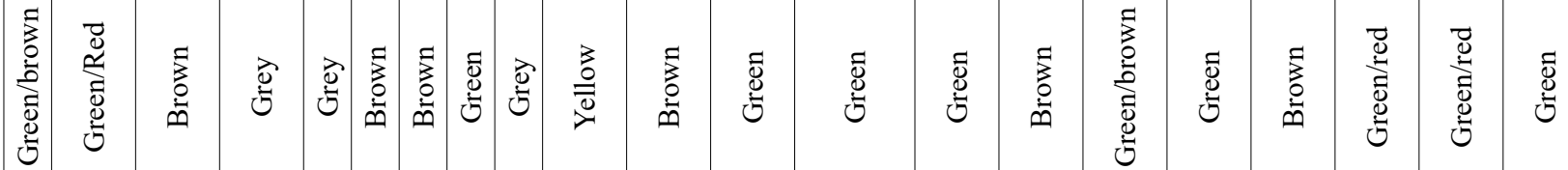

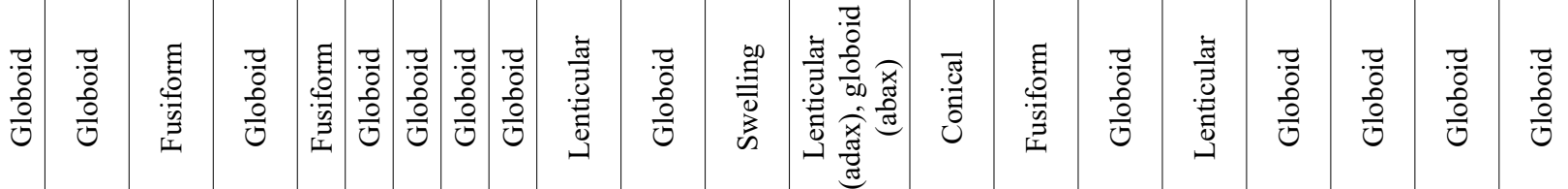

离

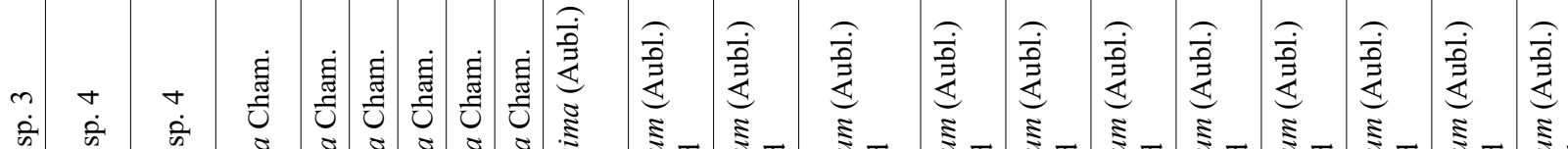

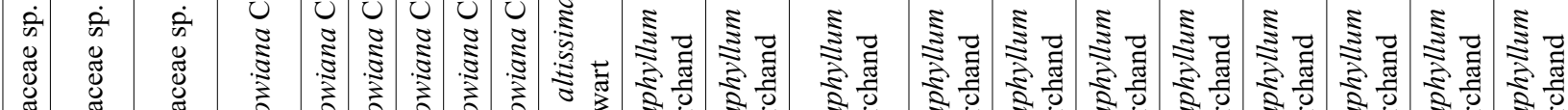

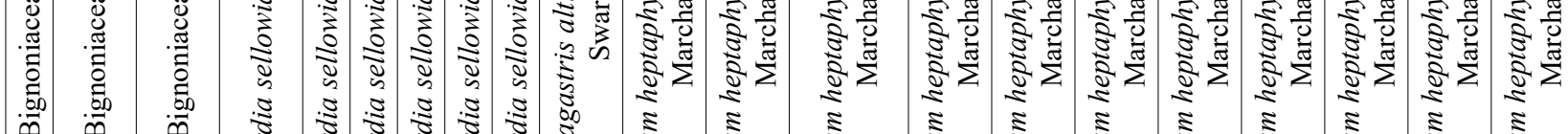

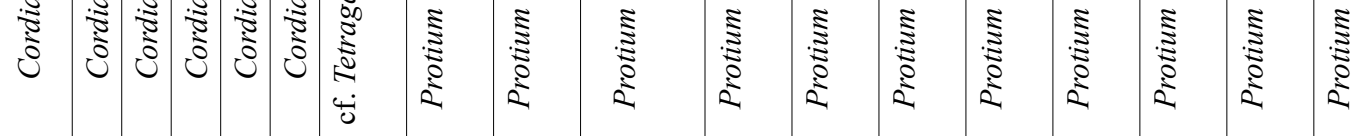

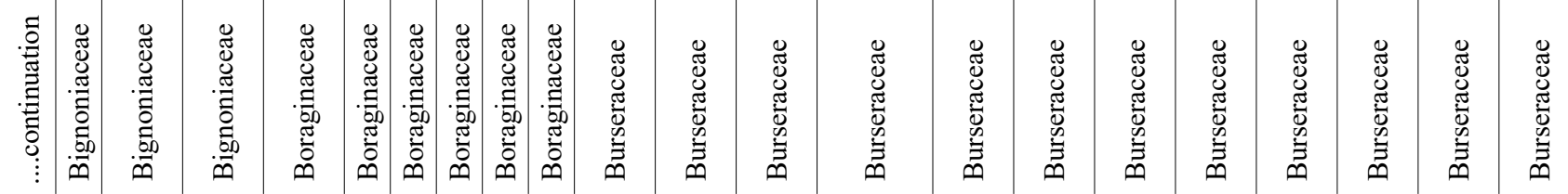




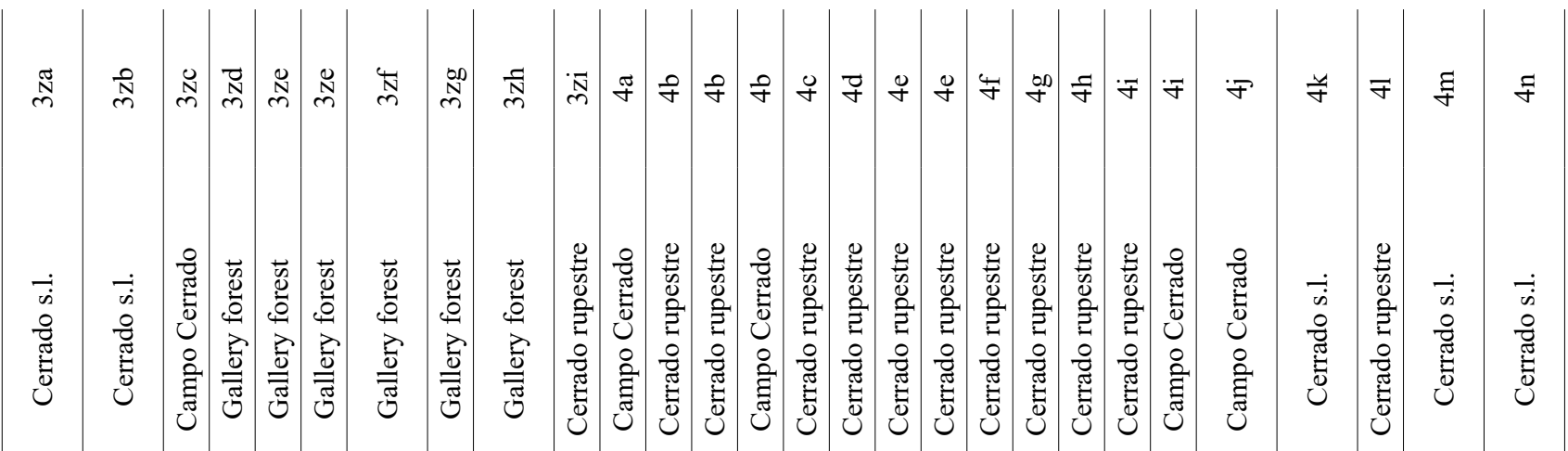

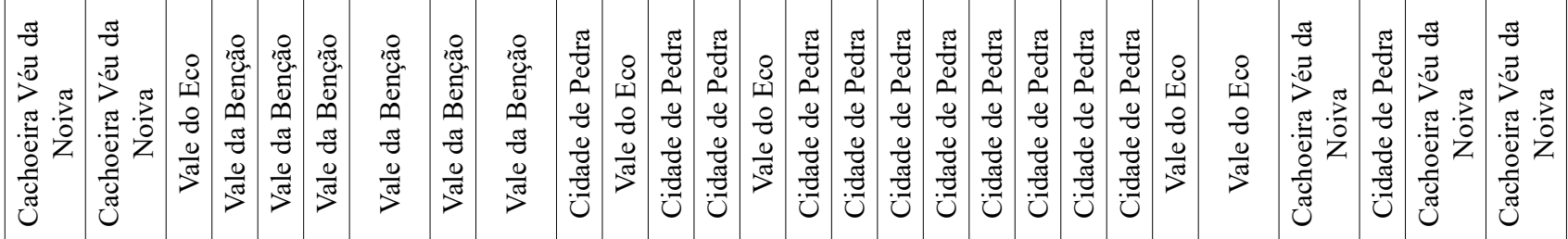

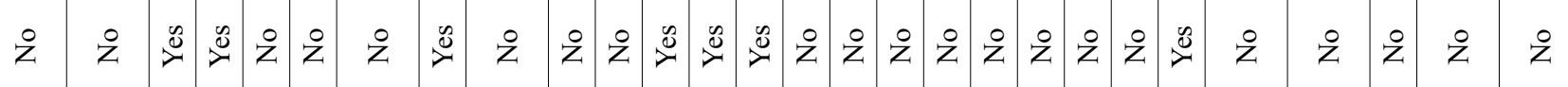

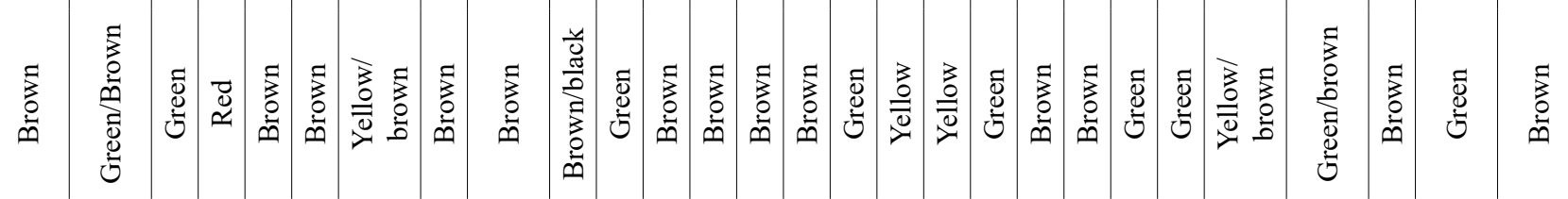

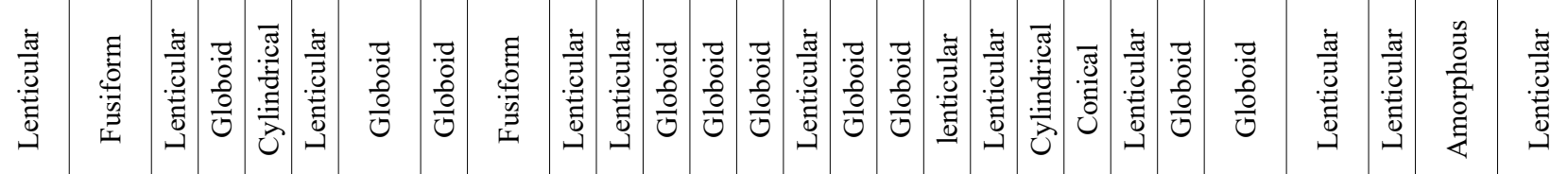

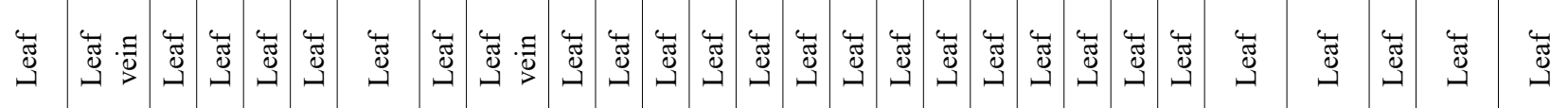

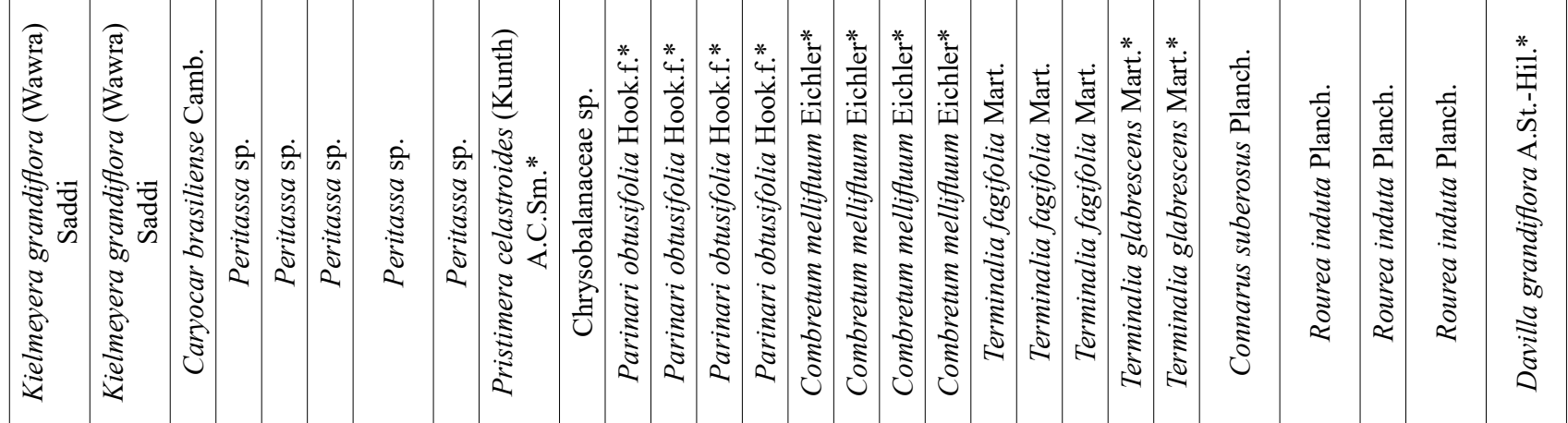

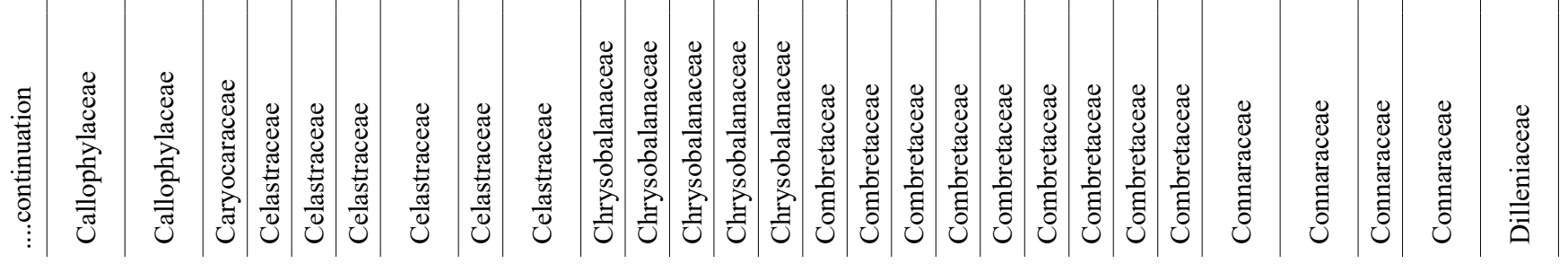




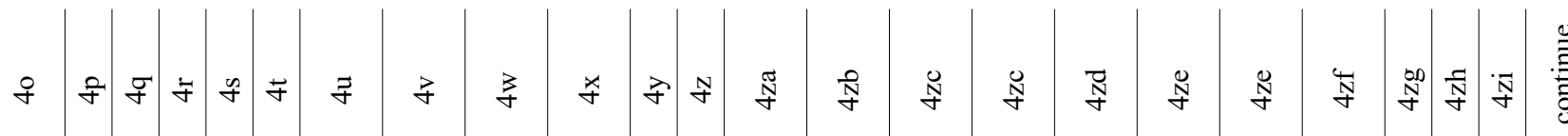

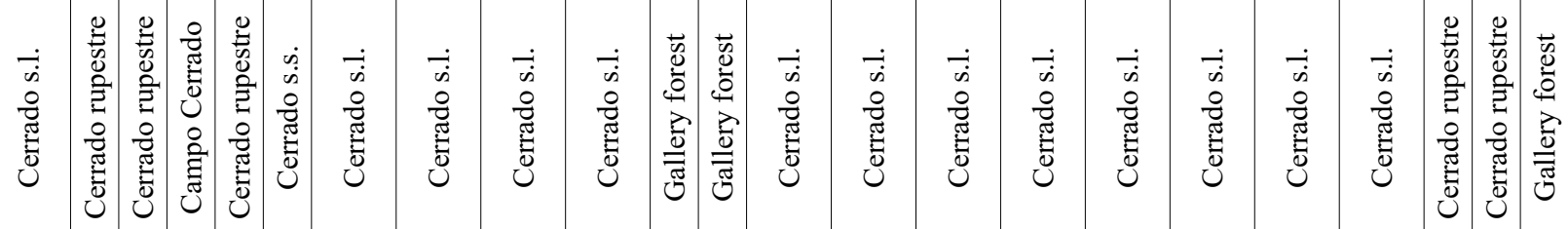

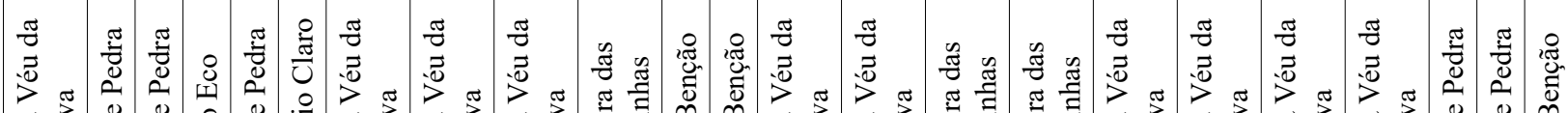

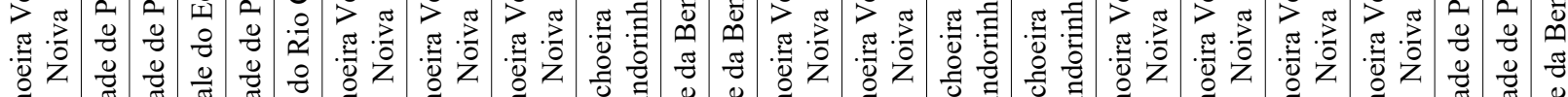

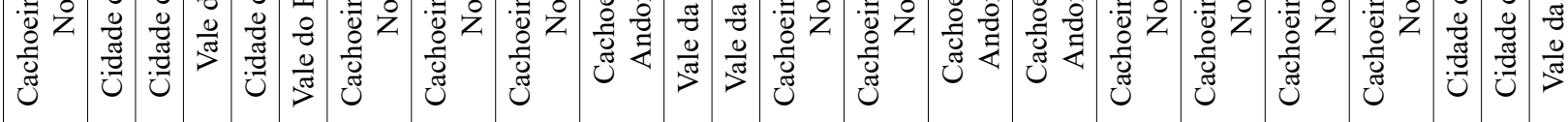

z

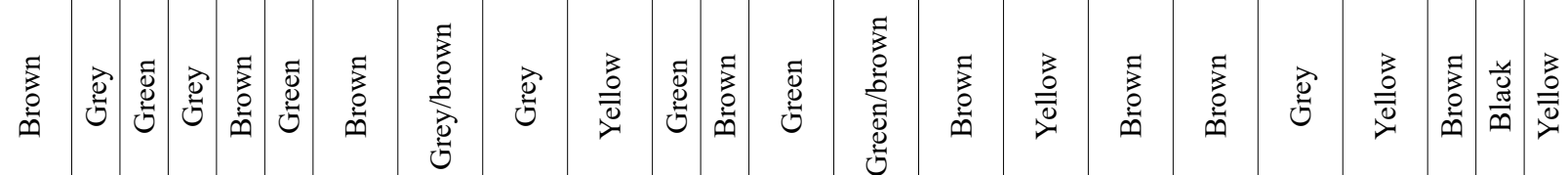

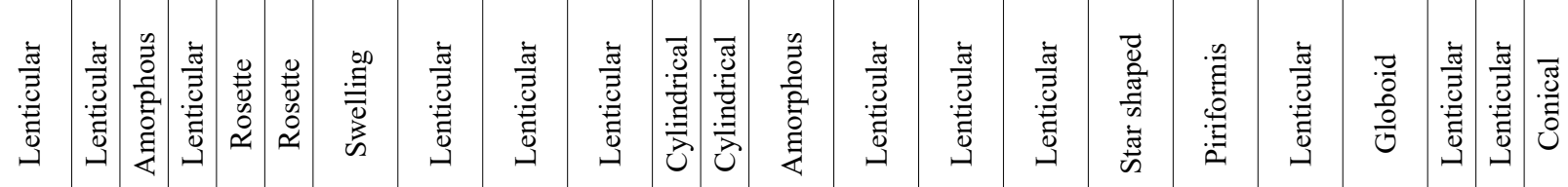
岕

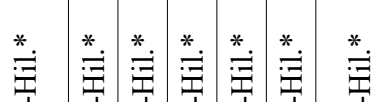
1.

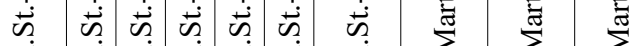

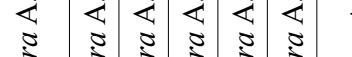

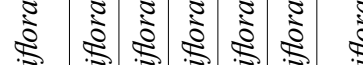

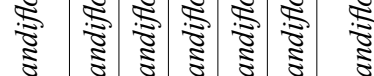

के

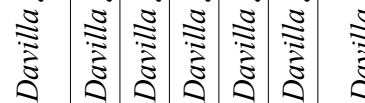

范

胥

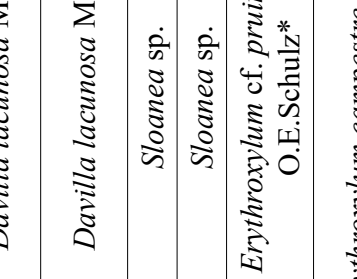

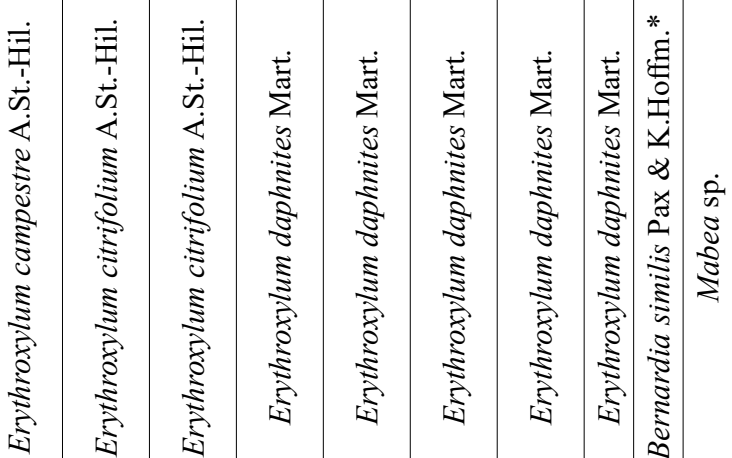
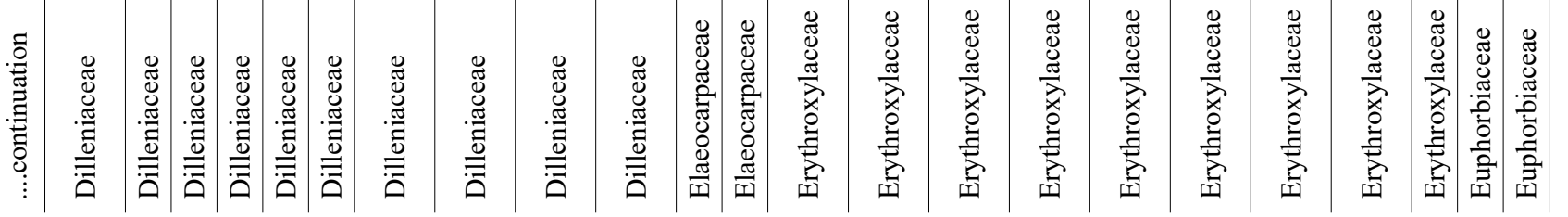


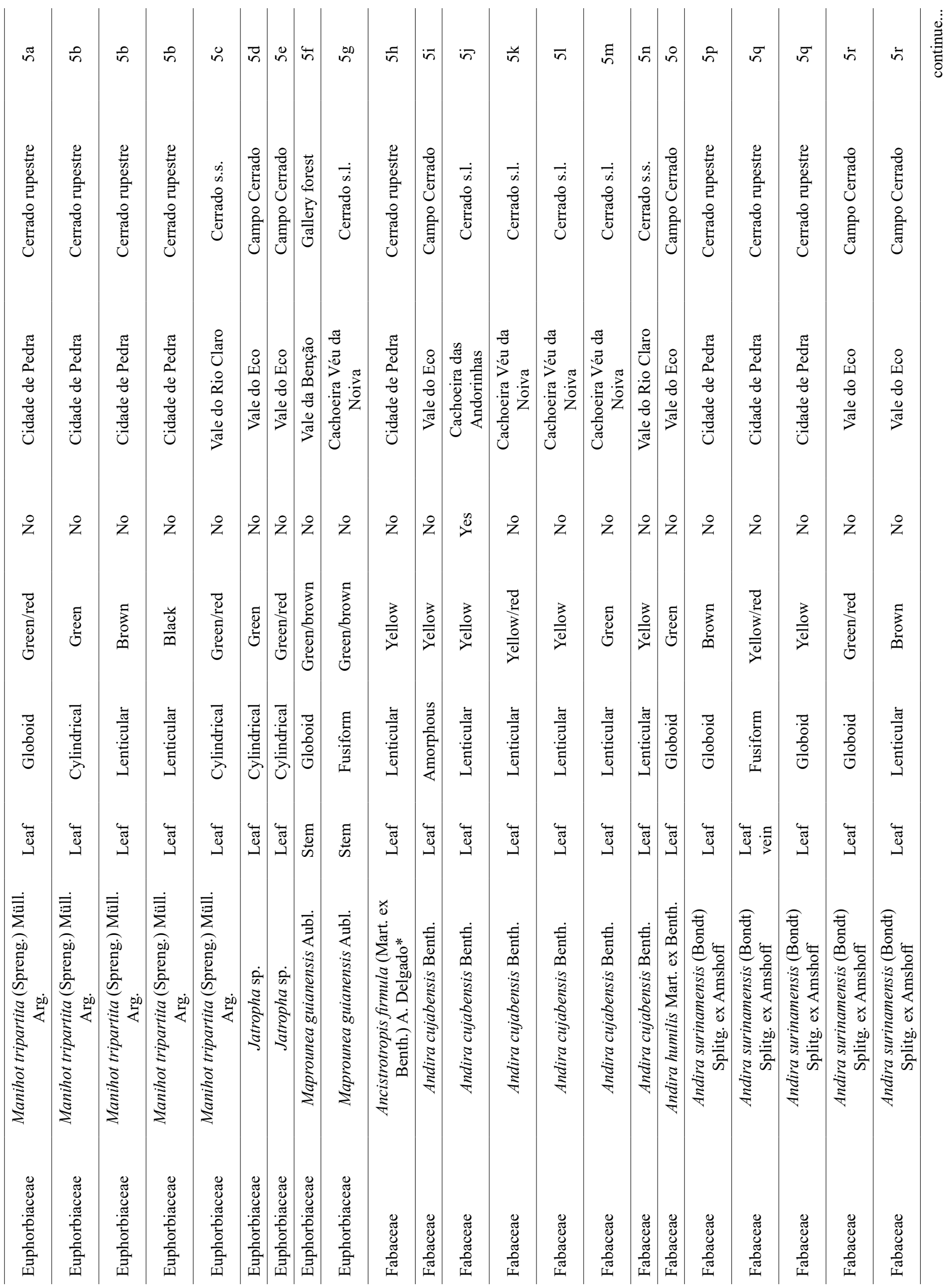


兵|

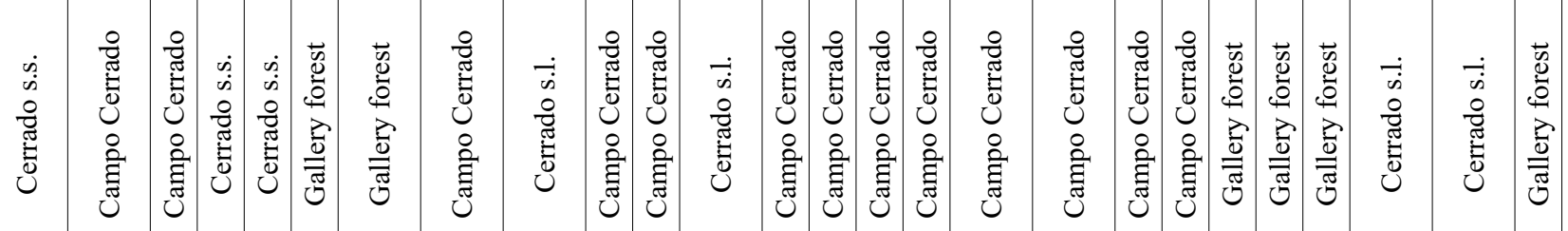

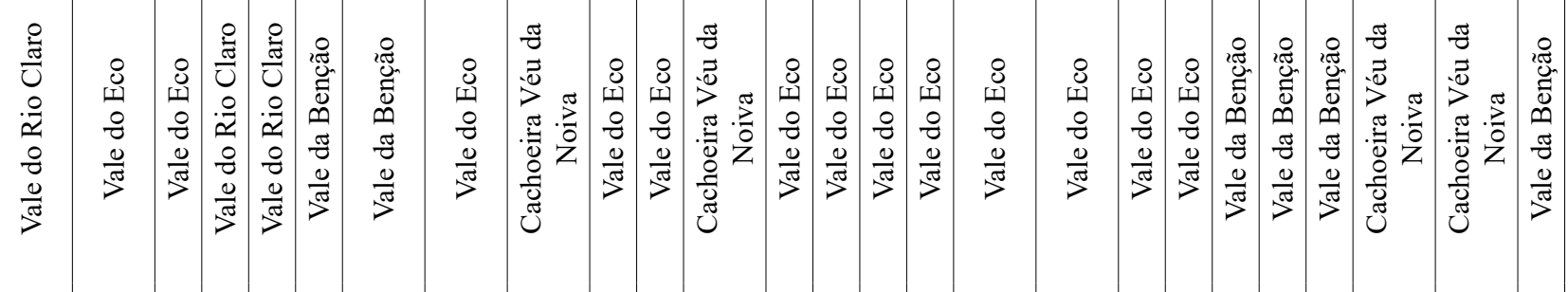

ż ż żz

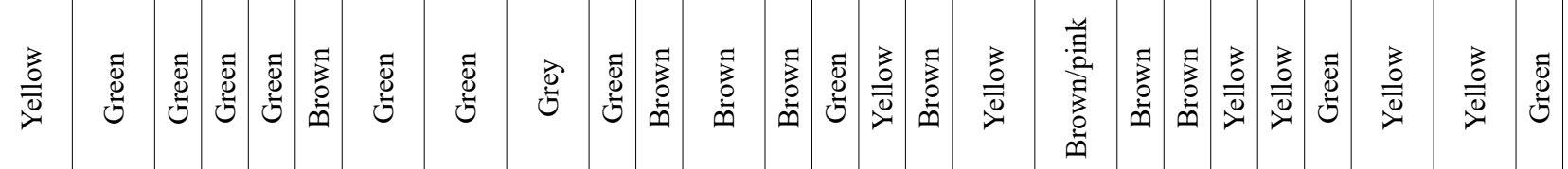

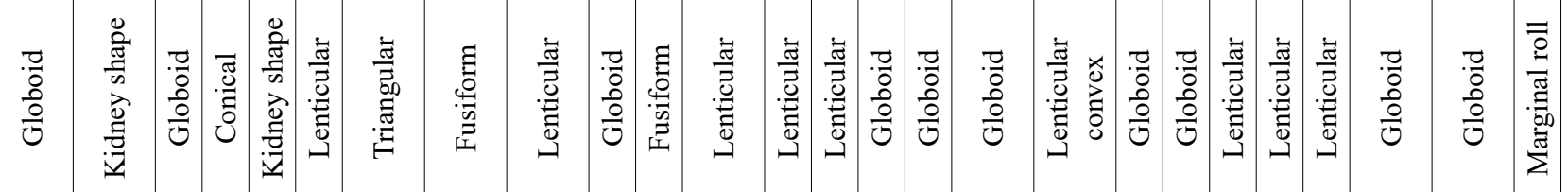

岕

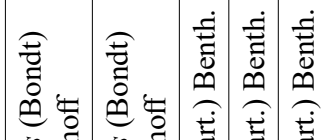

ह

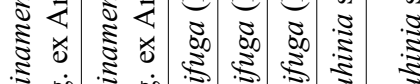

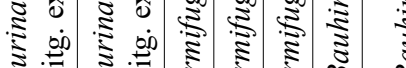

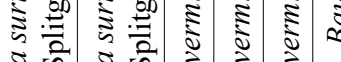

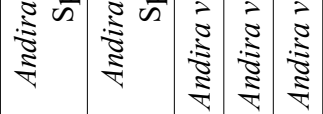

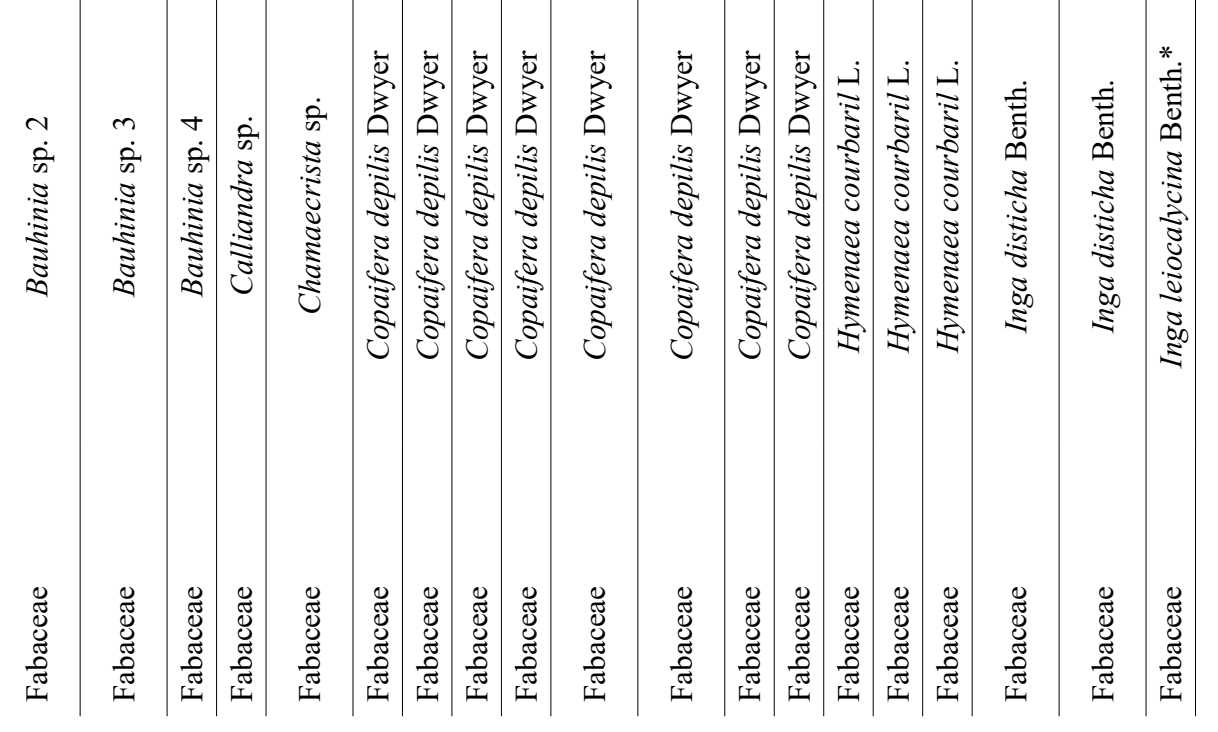


Urso-Guimarães, et al.

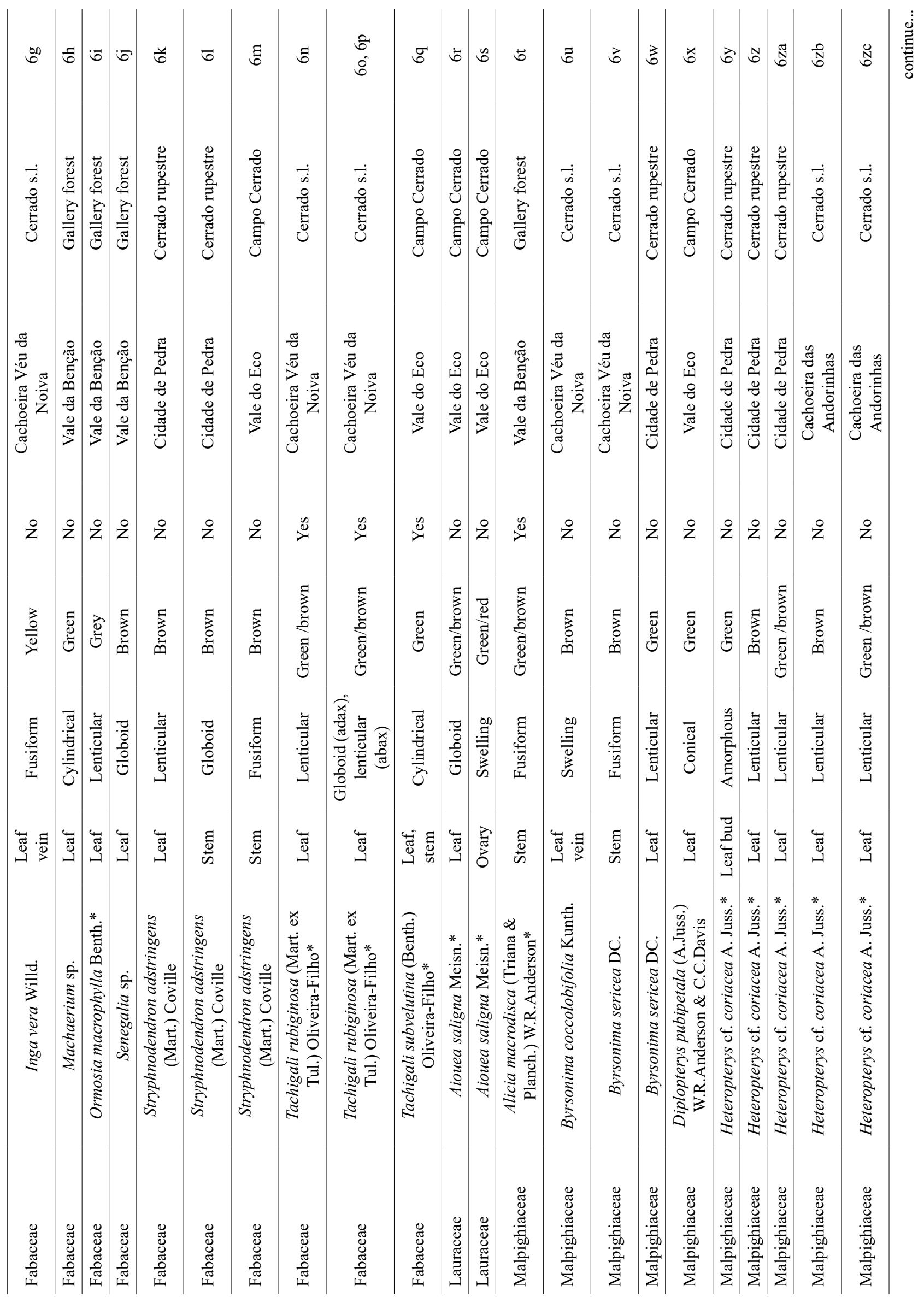


馬

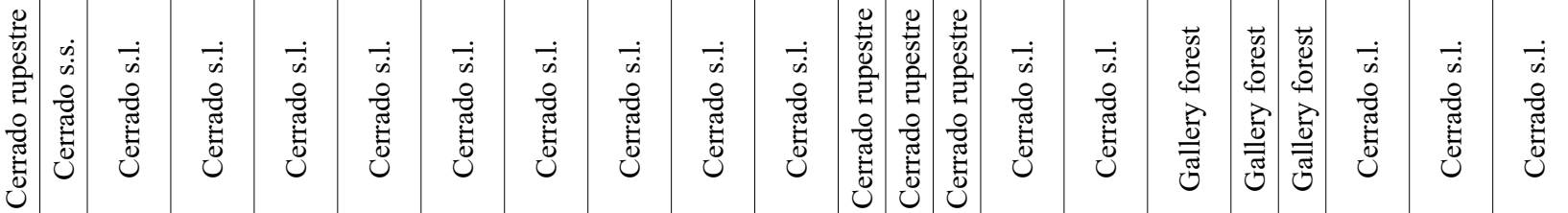

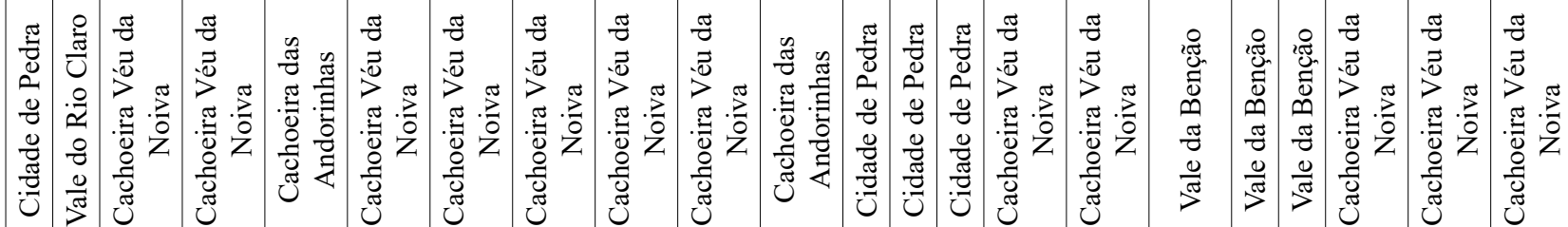

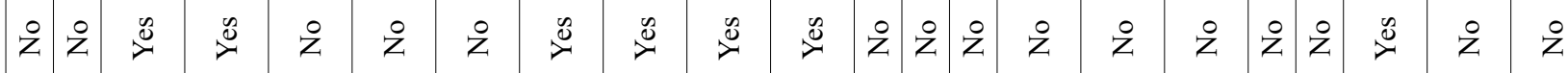

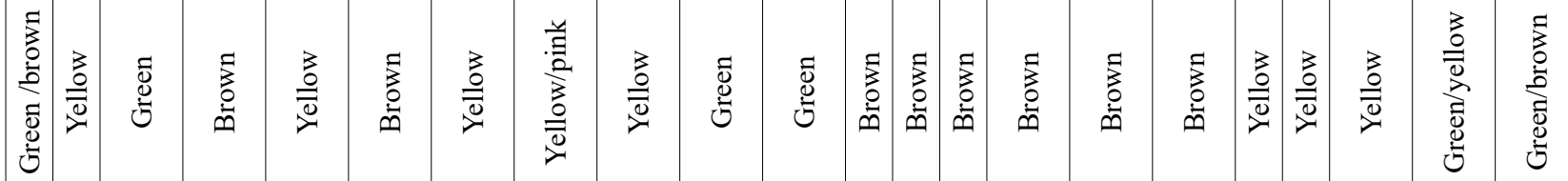

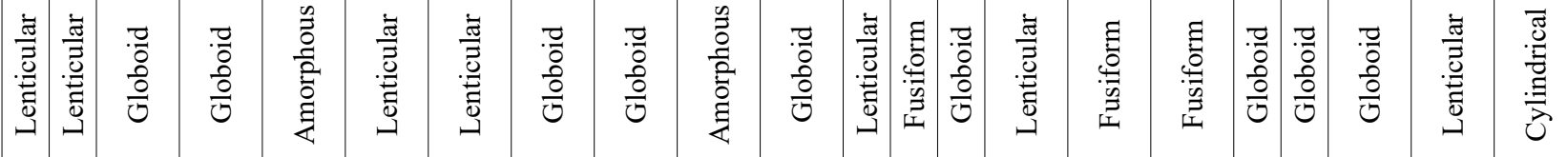

崖

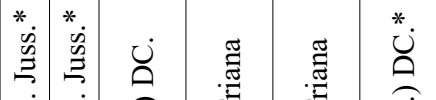



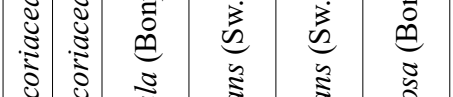

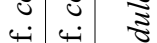

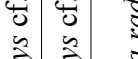

है

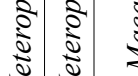

: $)$

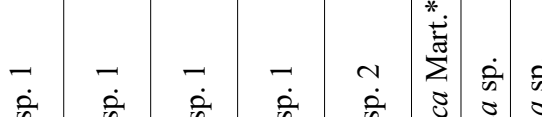

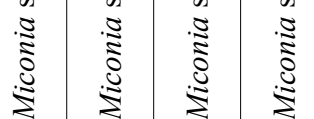

$\Xi$

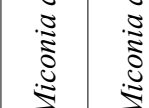

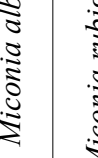

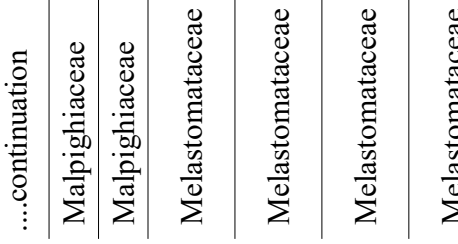

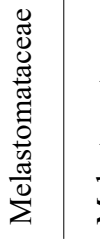

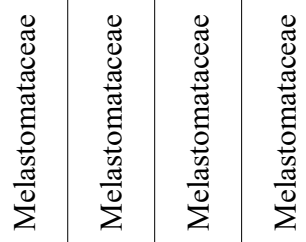

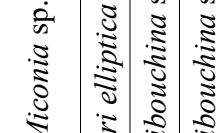

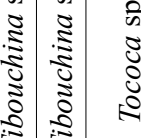

§

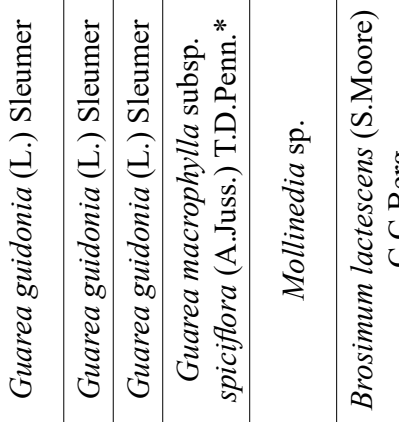




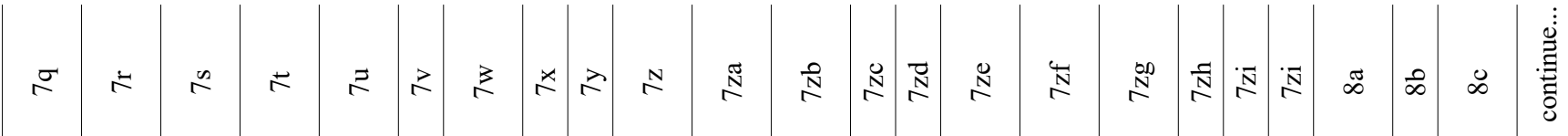

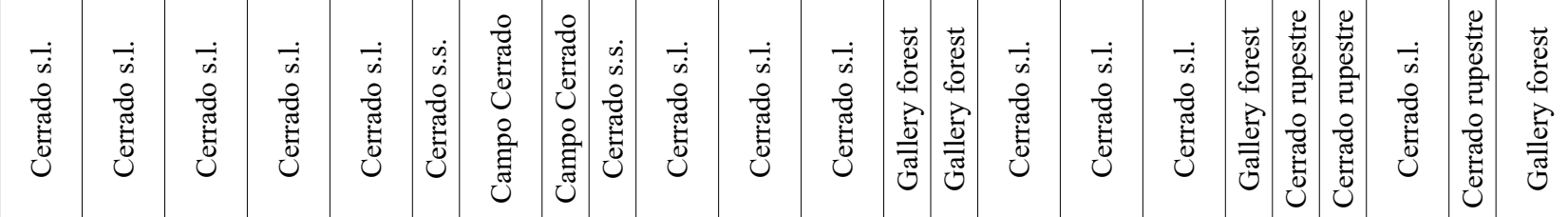

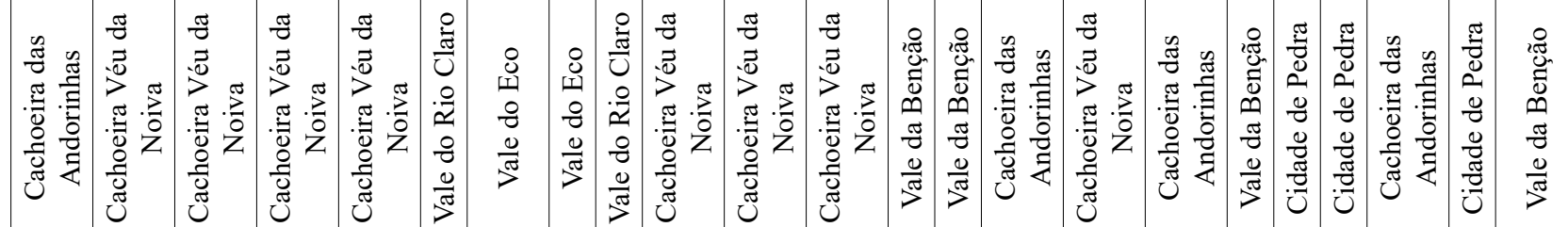

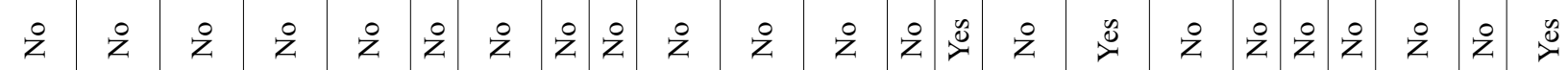

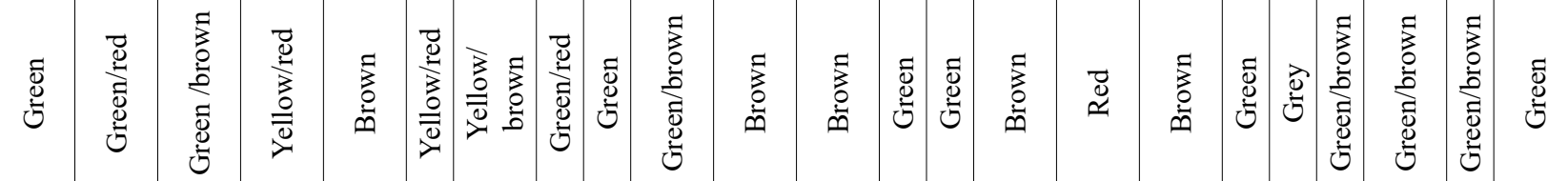

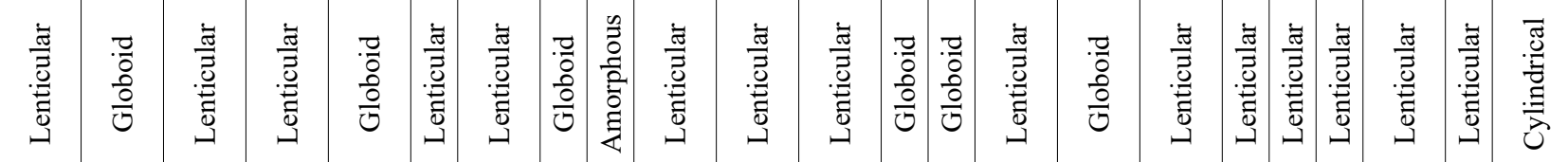$$
\text { 峁 }
$$

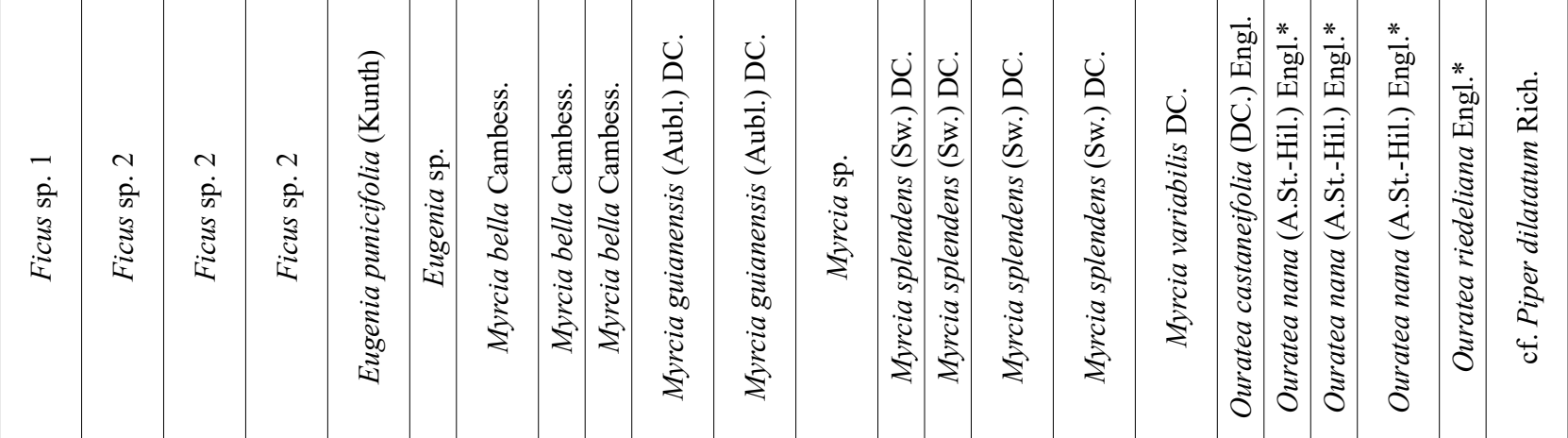

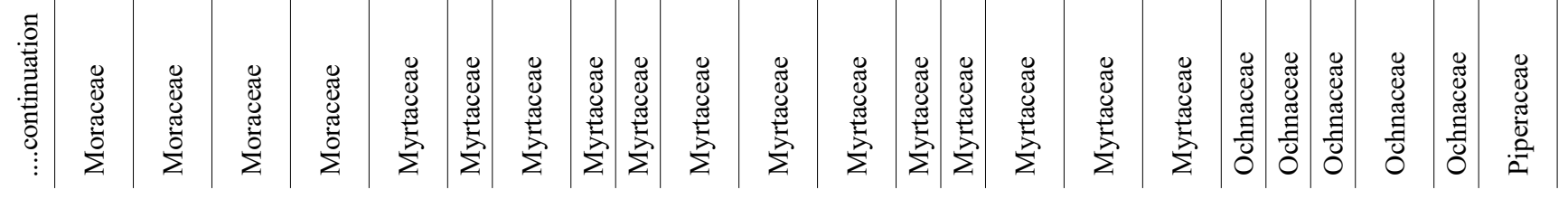




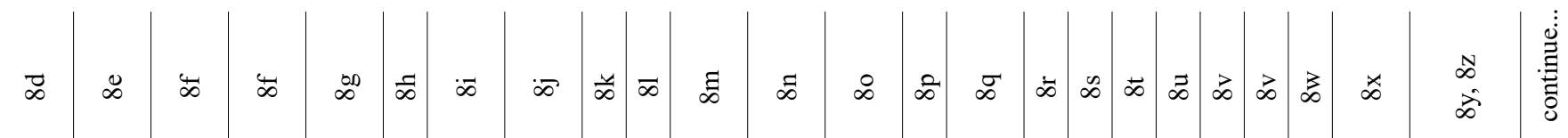

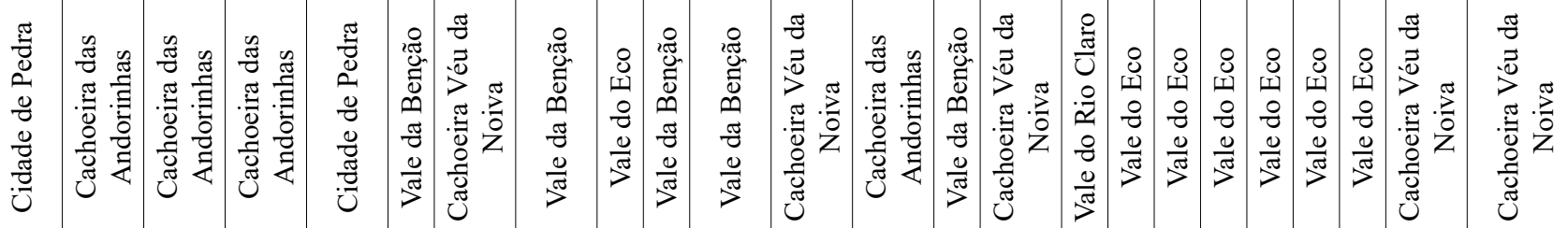

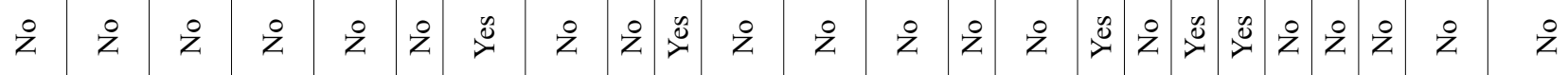

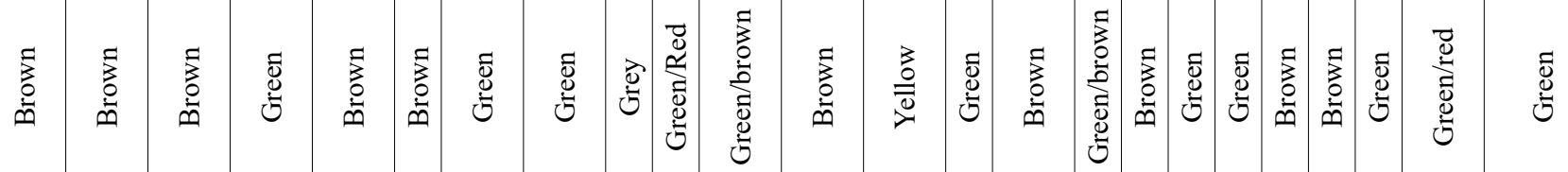

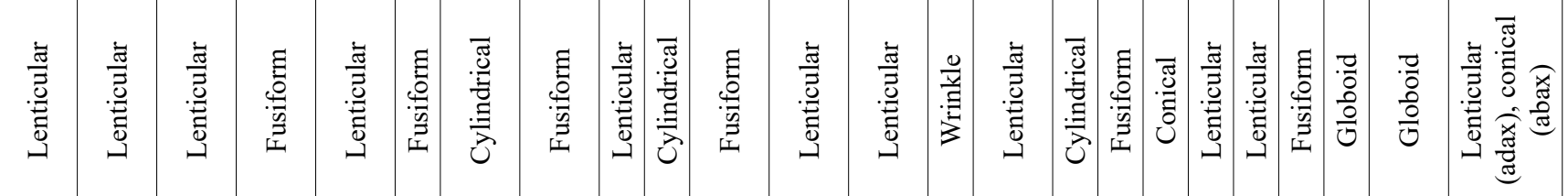

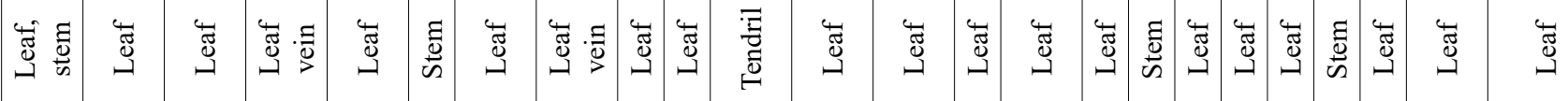

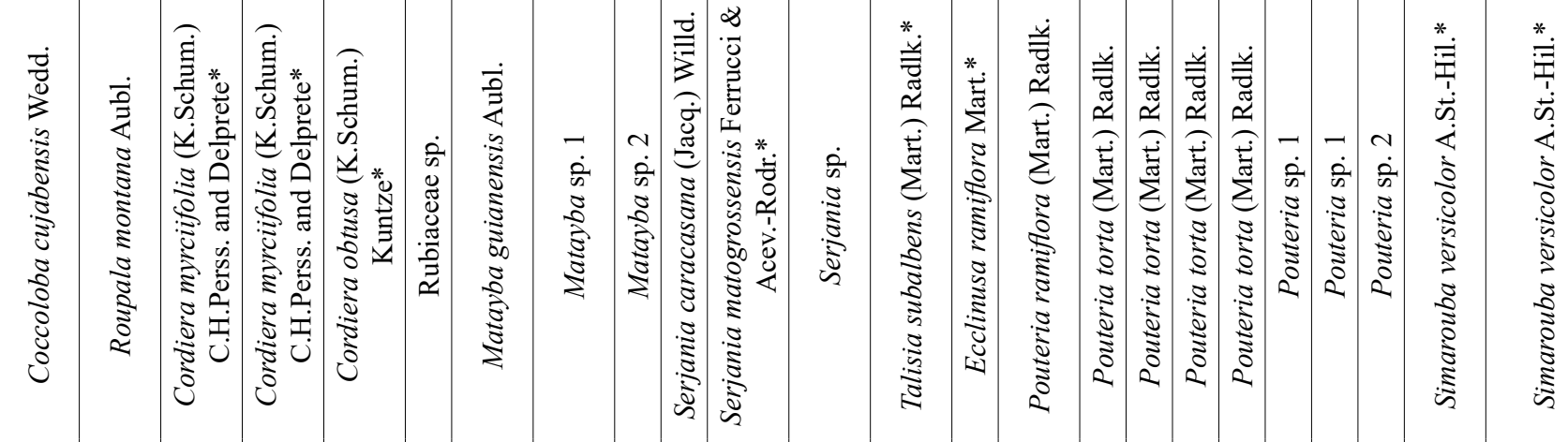

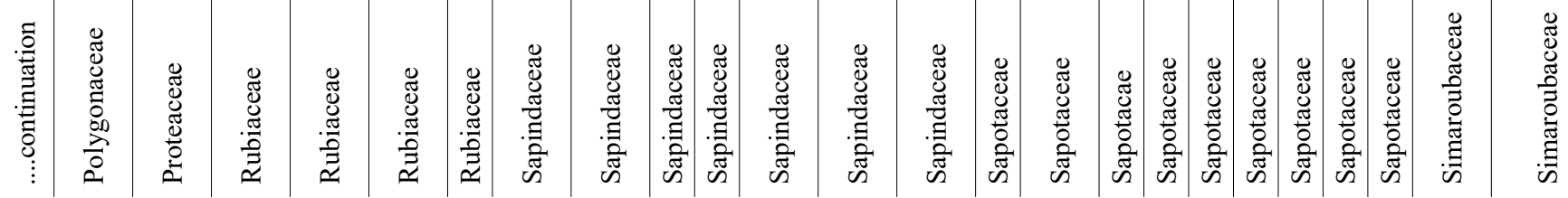




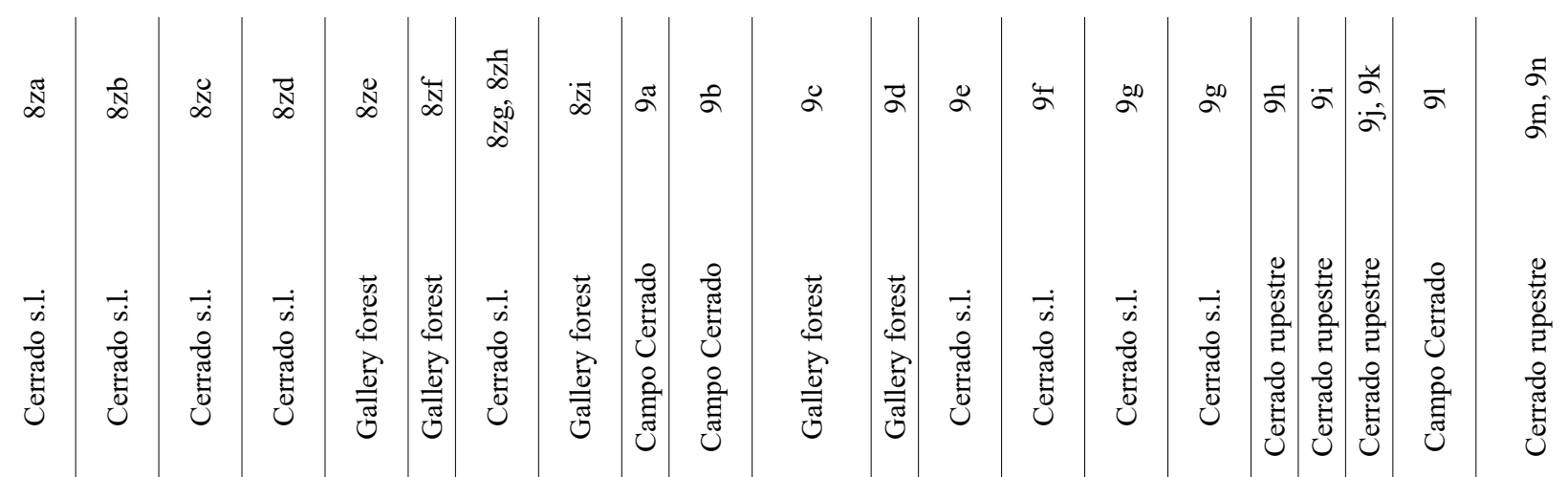

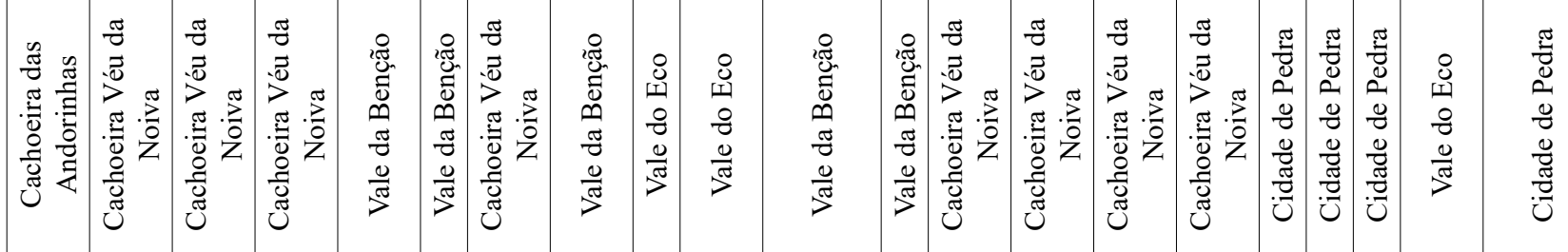

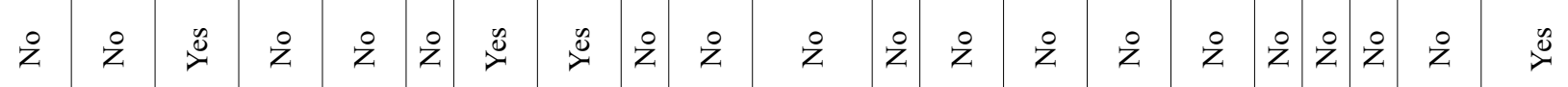

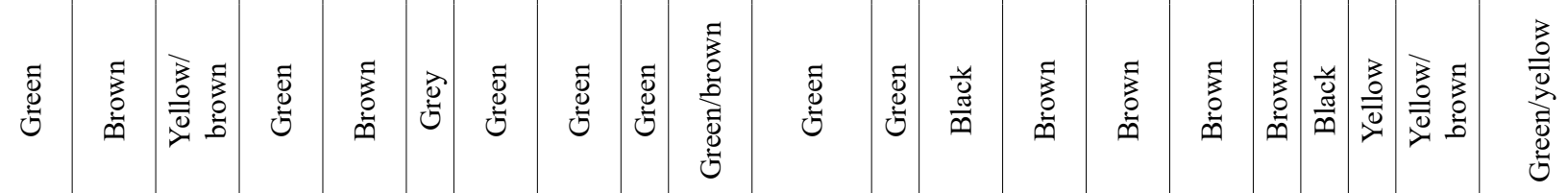

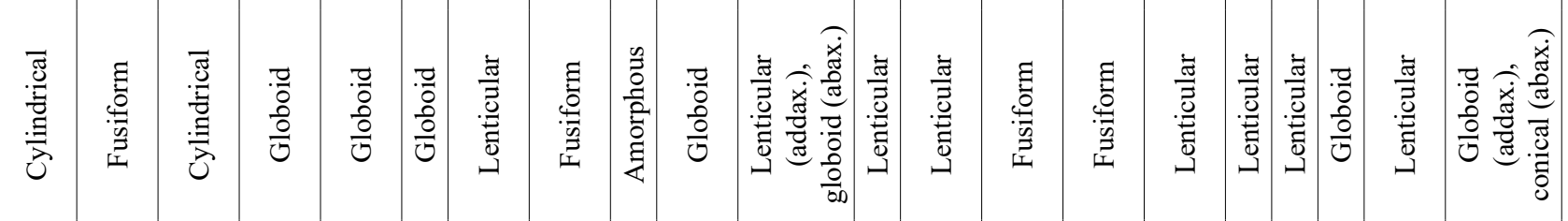

崖

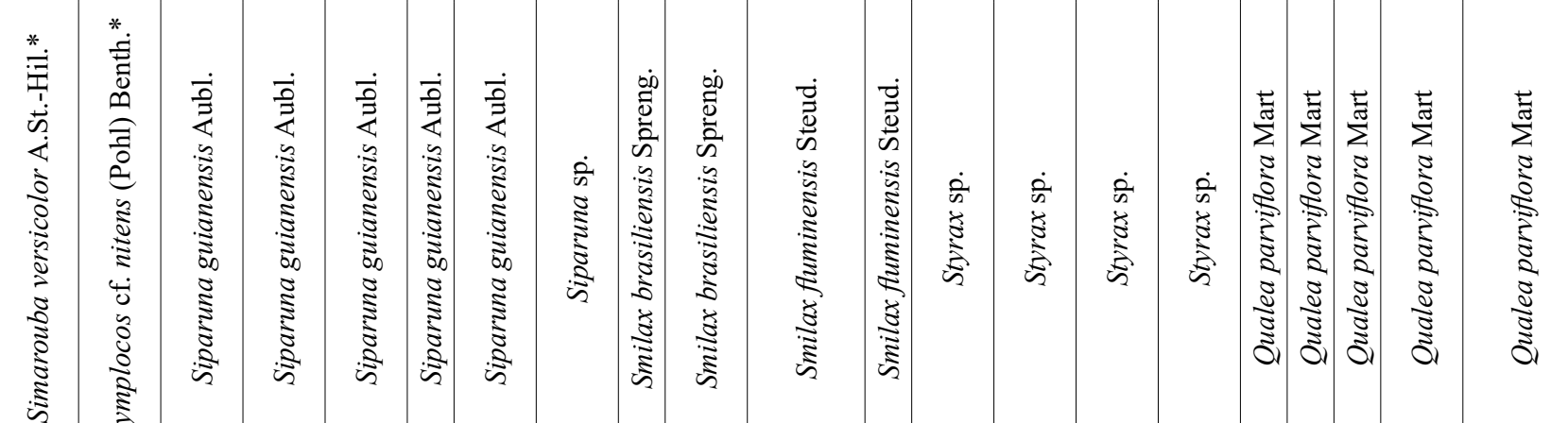

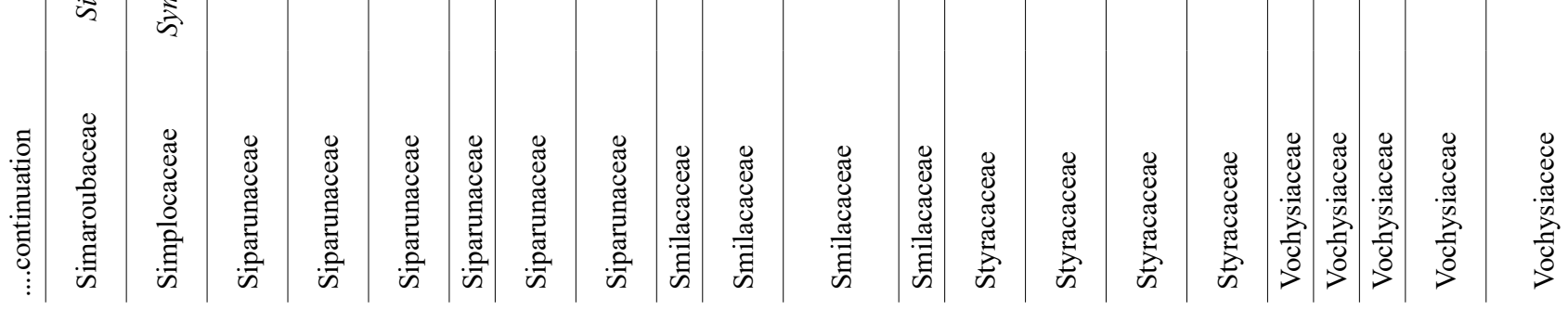




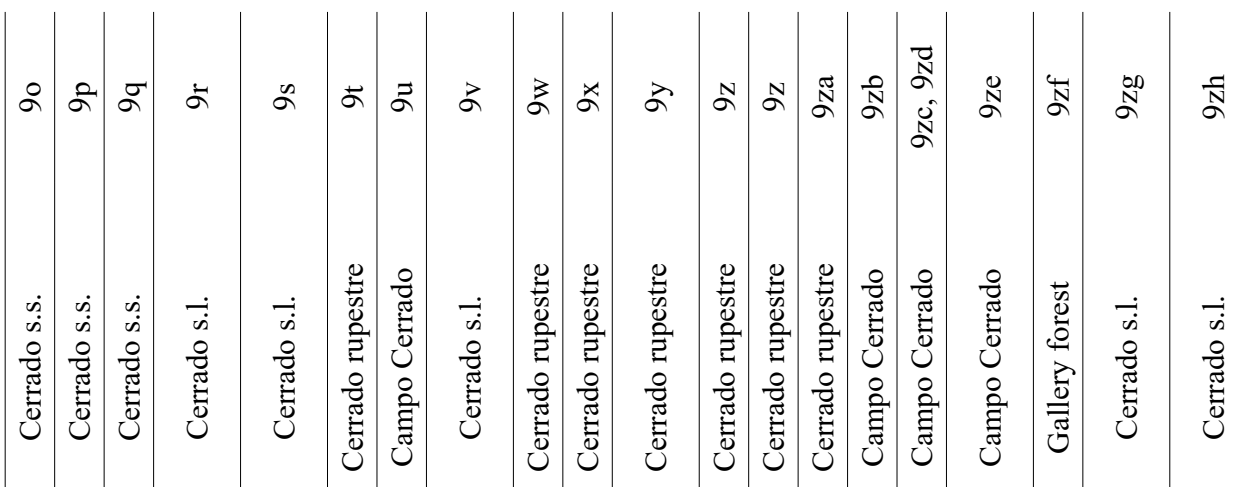

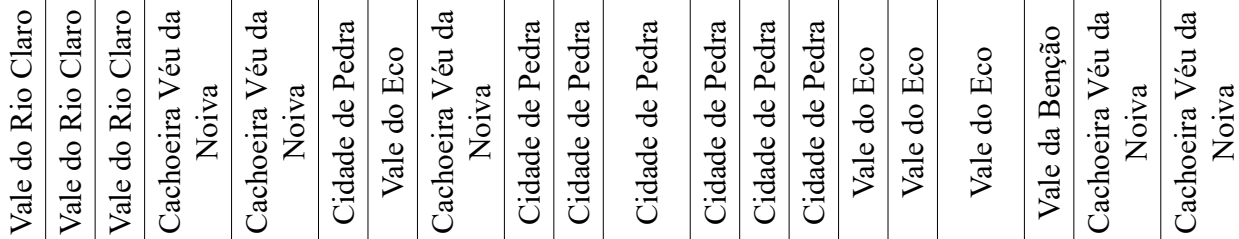

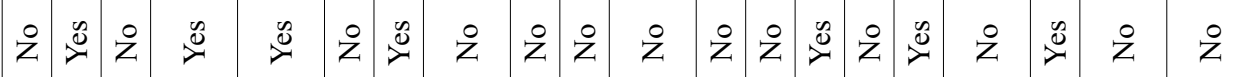

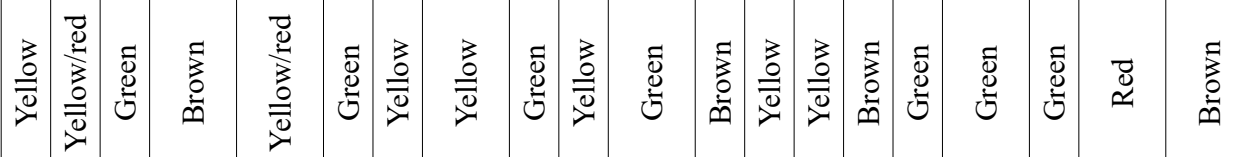

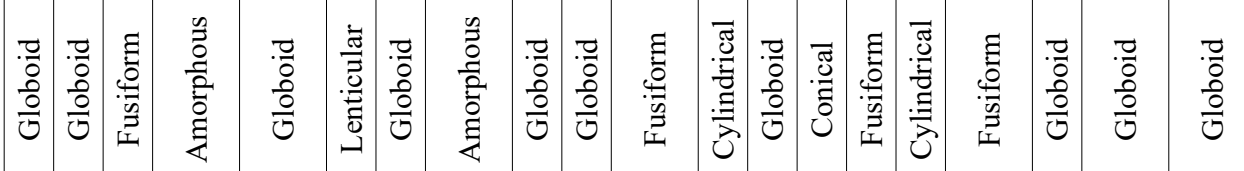

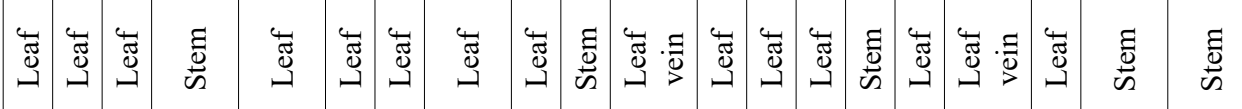

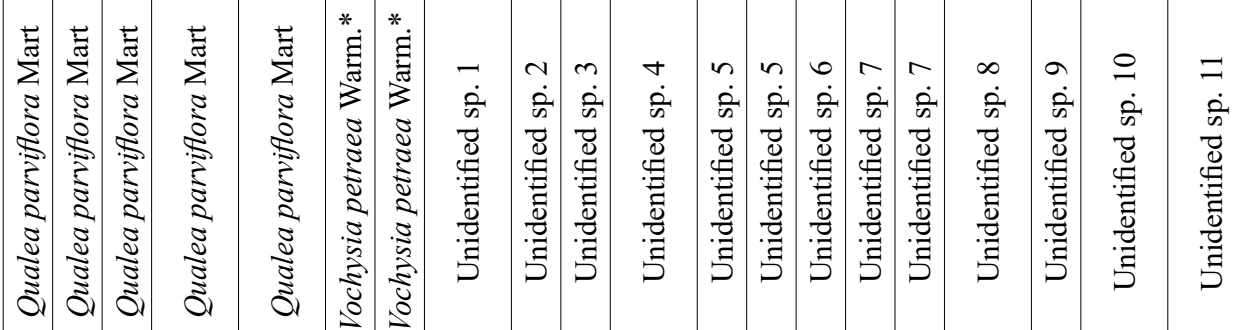

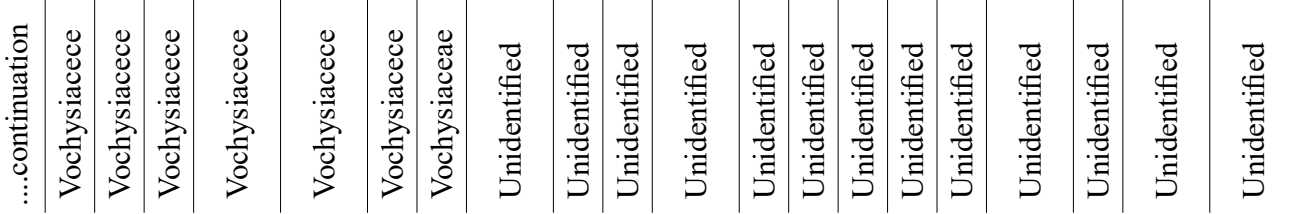


Urso-Guimarães, et al.

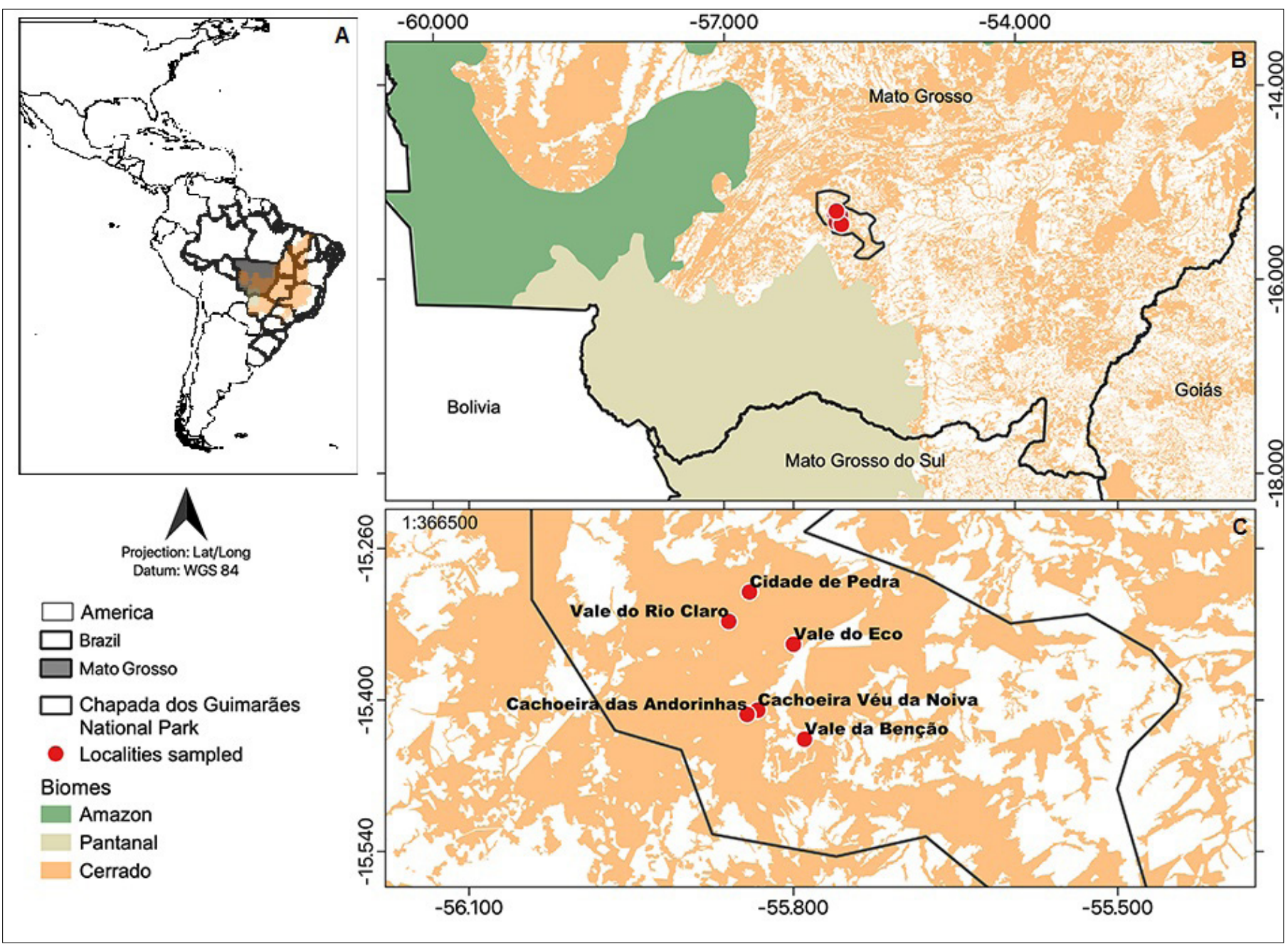

Figure 1. A. Map of South America indicating the Mato Grosso State and Cerrado Biome extension in Brazil. B. Map of the main biomes of Mato Grosso State and the position of Parque Nacional da Chapada dos Guimarães in Mato Grosso State. C. Map of the sampling localities of Parque Nacional da Chapada dos Guimarães, Mato Grosso State, Brazil.

families in morphotypes of insect galls were Fabaceae ( $\mathrm{N}=49,16.7 \%)$, Bignoniaceae $(\mathrm{N}=16,5.4 \%)$, Melastomataceae, and Myrtaceae $(\mathrm{N}=13$, $4.4 \%$ each), Burseraceae, Malpighiaceae, and Vochysiaceae $(\mathrm{N}=12$, $4.1 \%$ each). The richest plant genera in gall morphotypes were Andira Lam. (N=17; 5.8\%), Myrcia DC., Davilla Vand. and Protium Burm.f. $(\mathrm{N}=11 ; 3.7 \%)$, and Protium heptaphyllum (Aubl.) Marchand ( $\mathrm{N}=11$, $3.7 \%)$, Qualea parviflora Mart (N=10,3.4\%), Davilla grandiflora A.St.-Hil. and Copaifera depilis Dwyer ( $\mathrm{N}=8,2.7 \%$ each) are the studied area's super host species. The organ most affected were the leaves $(\mathrm{N}=250 ; 85 \%)$; the lenticular $(\mathrm{N}=104,35.4 \%)$ and globoid gall shapes $(\mathrm{N}=96,32.5 \%)$ were predominant, as the color green and its variations $(\mathrm{N}=129 ; 43.9 \%)$ and the glabrous galls $(\mathrm{N}=239 ; 81.3 \%)$.

From the insect galls, $91(30 \%)$ of the gall inducers were obtained and identified in 66 host plant species. The gall makers of 218 morphotypes are undetermined because the material collected were empty. In 11 cases the specimens obtained were damaged or with insufficient information to the identification. Among the insect gall inducers, $51 \%$ belong to Diptera ( $\mathrm{N}=45), 22.5 \%$ to Hymenoptera $(\mathrm{N}=20)$, followed by far by Coleoptera $(\mathrm{N}=6,6.7 \%)$, Hemiptera $(\mathrm{N}=4$, $4.5 \%)$ and Thysanoptera $(\mathrm{N}=2,2.2 \%)$ and Lepidoptera $(\mathrm{N}=1,1 \%)$. We identified eleven species of Cecidomyiidae: nine gall makers - three species of Lopesia Rübsaamen, two species of Asphondylia Loew and one species of each genus Bruggmannia Tavares, Dasineura Rondani, Stephomyia Tavares and Youngomyia Felt, and two species of the inquiline genus Trotteria Kieffer. Associated fauna and other details are in Table 4. One supplementary gall in Miconia albicans (Sw.) Triana (Melastomataceae) (Fig. 9G) was induced by fungus.

Aionea Aubl., Alicia W.R.Anderson, Ancistrotropis A. Delgado, Bernardia Houst. ex Mill., Peritassa Miers, Pleonotoma Miers, Pristimera Miers are new records as a host plant for insect galls. The same occurs with 38 host plant species (Table 2). Two host plant species are listed in the Red List of Threatened Species of the International Union for Conservation of Nature in the category "Threatened": Vochysia petraea Warm. as "Endangered" and Talisia subalbens (Mart.) Radlk. as "Vulnerable".

Additionally, Bernardia similis Pax and K.Hoffm and Ormosia macrophylla Benth. are registered for the first time in Mato Grosso State's flora (Flora do Brasil 2020).

\section{Discussion}

Even though comparisons of this study with others are hampered both, by the diversity of sampling methods used and by the presence of 

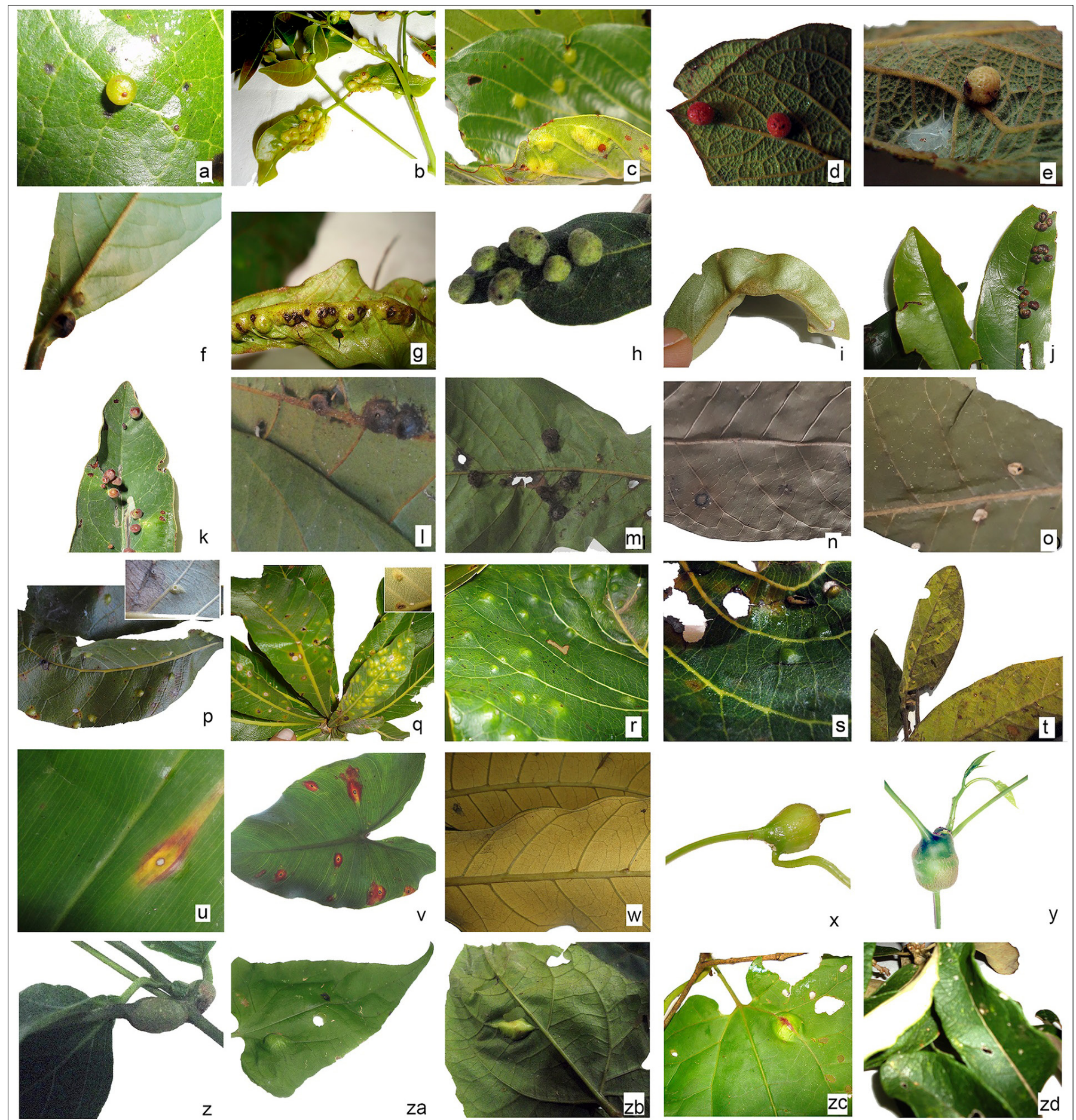

y
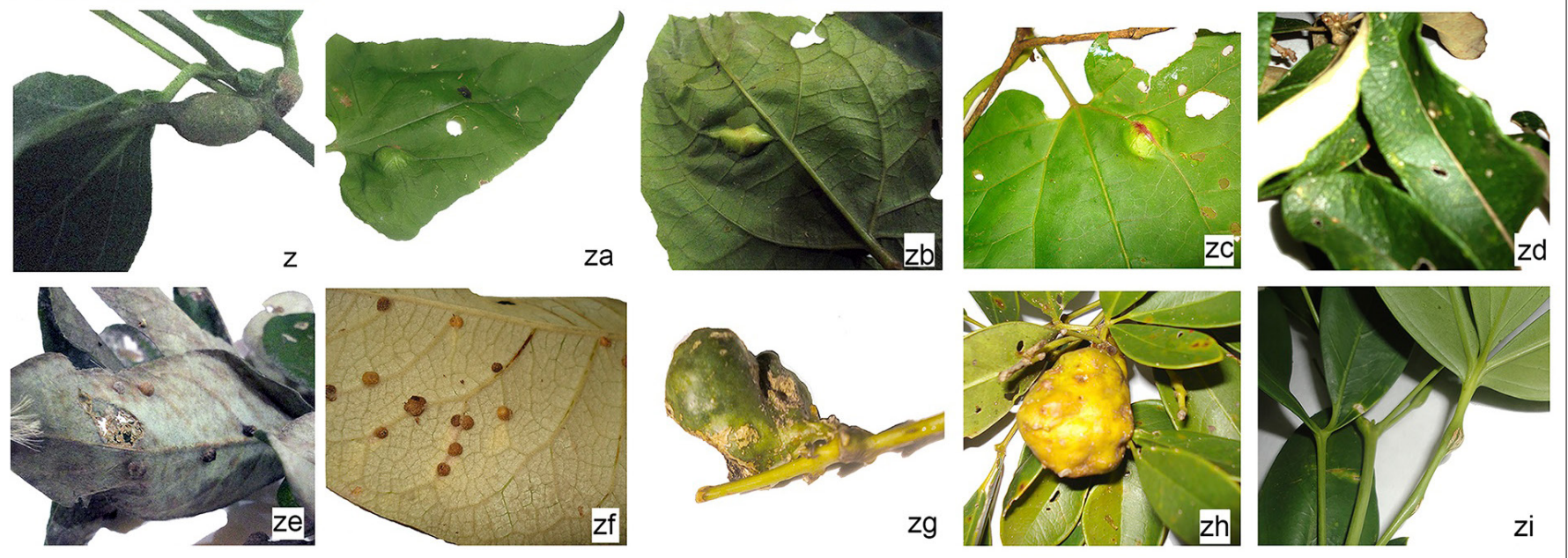

Figure 2. Insect galls of Parque Nacional da Chapada dos Guimarães, Mato Grosso State, Brazil in host plants indicated. Anacardiaceae. a. Anacardium nannum, b. Tapirira guianensis. Annonaceae. c. Annona dioica, d-e. Annona tomentosa, f-g. Duguetia flagellaris, h-k. Duguetia furfuracea, 1-m. Guatteria ferruginea, n. Unonopsis guatterioides. Apocynaceae. o. Aspidosperma subincanum, p-q. Aspidosperma tomentosum, r-s. Aspidosperma verbascifolium, t. Odontadenia lutea. Araceae. u-v. Philodendron sp. Araliaceae. w. Schefflera morototoni. Aristolochiaceae. x-y. Aristolochia sp. Asteraceae. z. Mikania sp., za-zc. Mikania cf. micrantha, zd-zf. Piptocarpha rotundifolia. Bignoniaceae. zg-zi. Anemopaegma glaucum. 
Urso-Guimarães, et al.

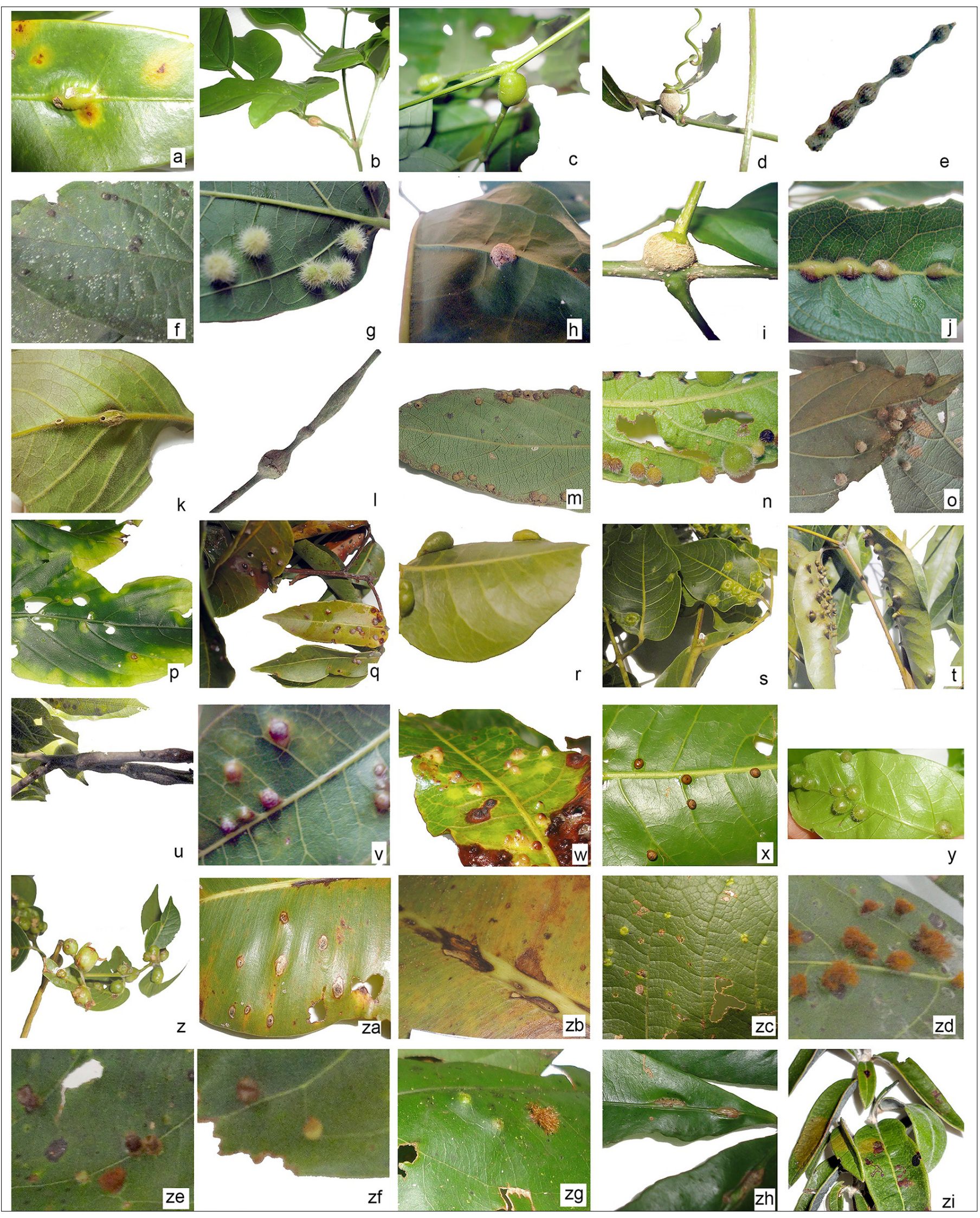

Figure 3. Insect galls of Parque Nacional da Chapada dos Guimarães, Mato Grosso State, Brazil in host plants indicated. Bignoniaceae. a. Anemopaegma glaucum. b-c. Pleonotoma sp., d. Bignoniaceae sp. 1, e-g. Bignoniaceae sp. 2, h-i. Bignoniaceae sp. 3, j-k. Bignoniaceae sp. 4. Boraginaceae. 1-o. Cordia sellowiana. Burseraceae. p. cf. Tetragastris altissima, q-z. Protium heptaphyllum. Callophylaceae. za-zb. Kielmeyera grandiflora. Caryocaraceae. zc. Caryocar brasiliense. Celastraceae. zd-zg. Peritassa sp. zh. Pristimera celastroides. Chrysobalanaceae. zi. Chrysobalanaceae sp. 


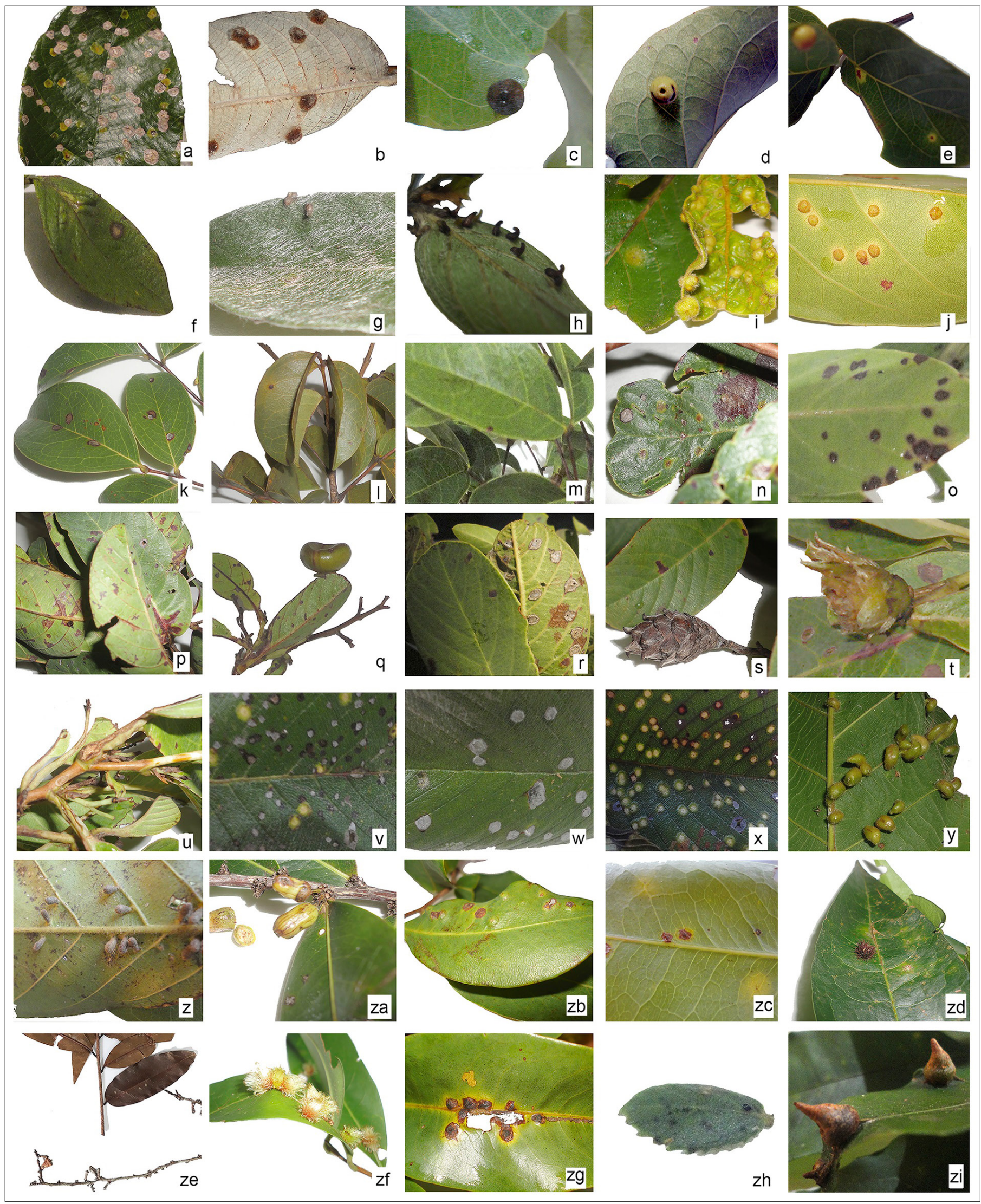

Figure 4. Insect galls of Parque Nacional da Chapada dos Guimarães, Mato Grosso State, Brazil in host plants indicated. Chrysobalanaceae. a-b. Parinari obtusifolia. Combretaceae. c-e. Combretum mellifluum, f-h. Terminalia fagifolia, i. Terminalia glabrescens. Connaraceae. j. Connarus suberosus, k-m. Rourea induta. Dilleniaceae n-u. Davilla grandiflora, v-x. Davilla lacunosa. Elaeocarpaceae. y-z. Sloanea sp. Erythroxylaceae. za. Erythroxylum cf. pruinosum. zb. Erythroxylum campestre, zc. Erythroxylum citrifolium, zd-zg. Erythroxylum daphnites. Euphorbiaceae. zh. Bernardia similis, zi. Mabea sp. 

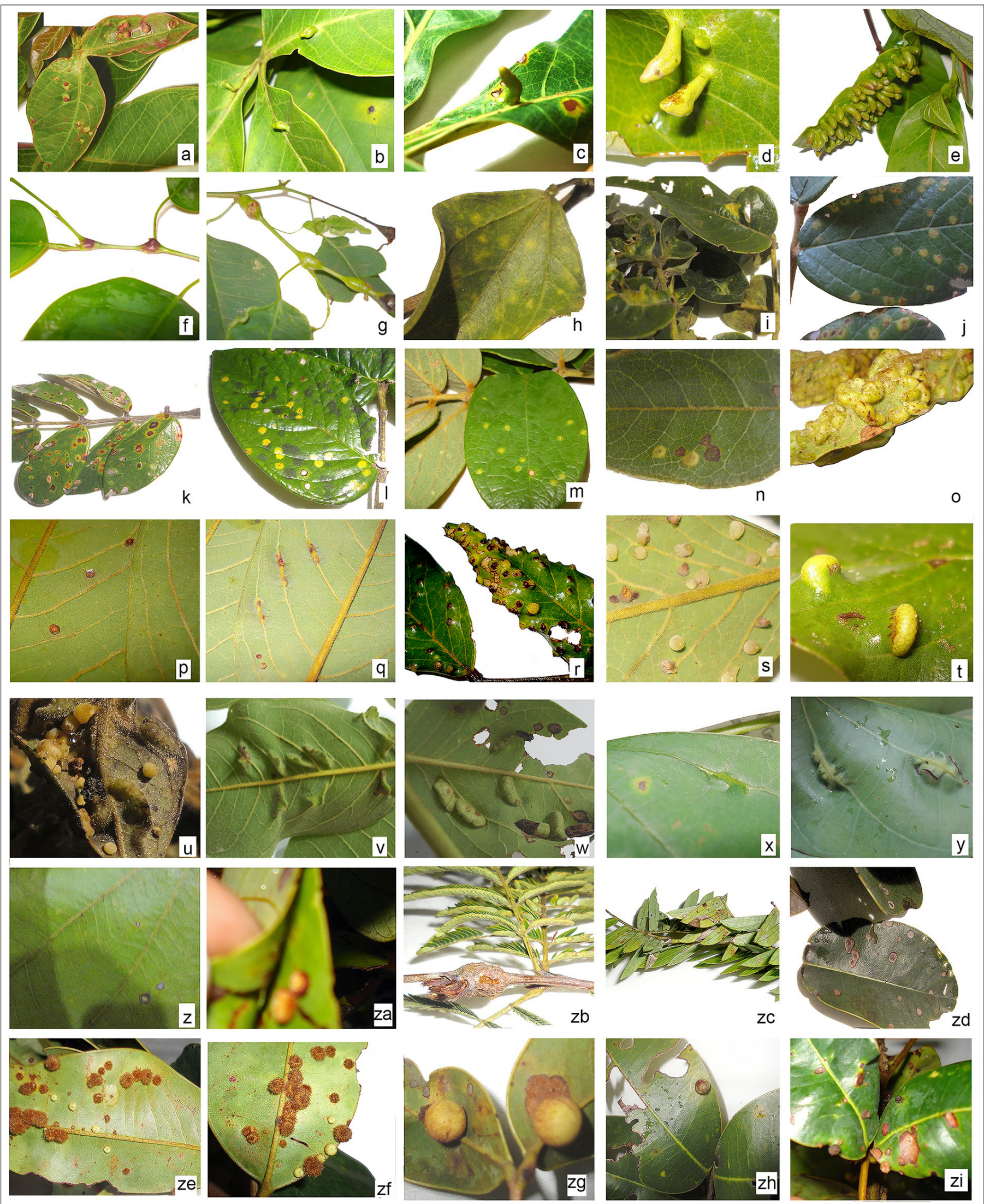

0

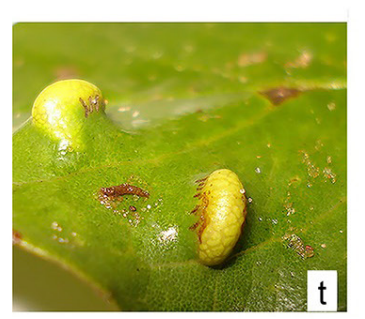

$x$
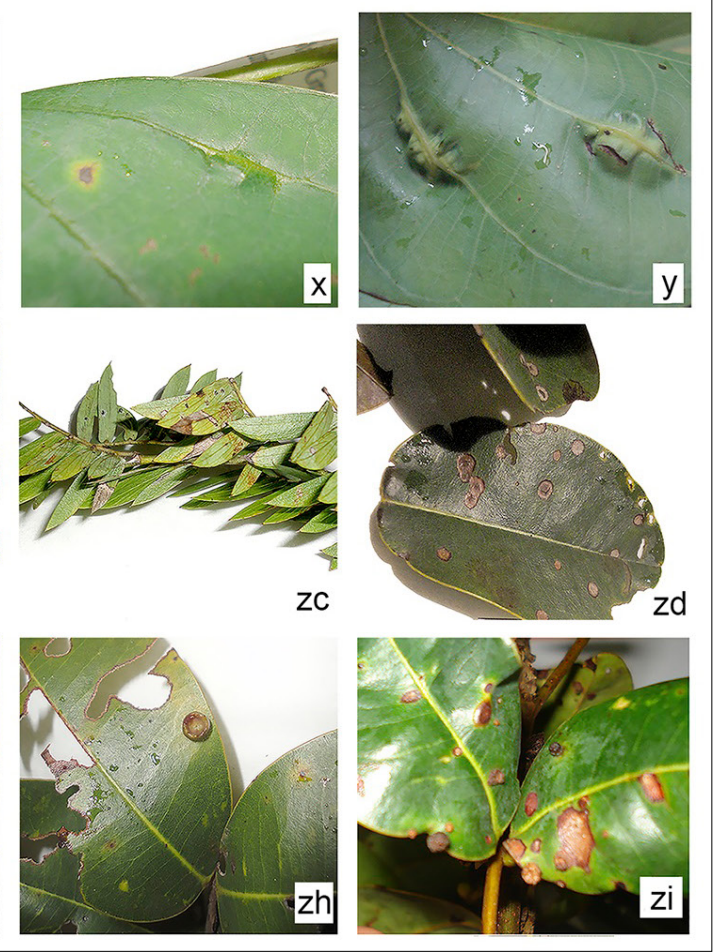

Figure 5. Insect galls of Parque Nacional da Chapada dos Guimarães, Mato Grosso State, Brazil in host plants indicated. Euphorbiaceae. a-c. Manihot tripartita, d-e. Jatropha sp., f-g. Maprounea guianensis. Fabaceae. h. Ancistrotropis formula, i-n. Andira cujabensis, o. Andira humilis, p-t. Andira surinamensis, u-w. Andira vermifuga, x. Bauhinia sp. 1, y. Bauhinia sp. 2, z. Bauhinia sp. 3, za. Bauhinia sp. 4, zb. Calliandra sp., zc. Chamaecrista sp., zd-zi. Copaifera depilis. 

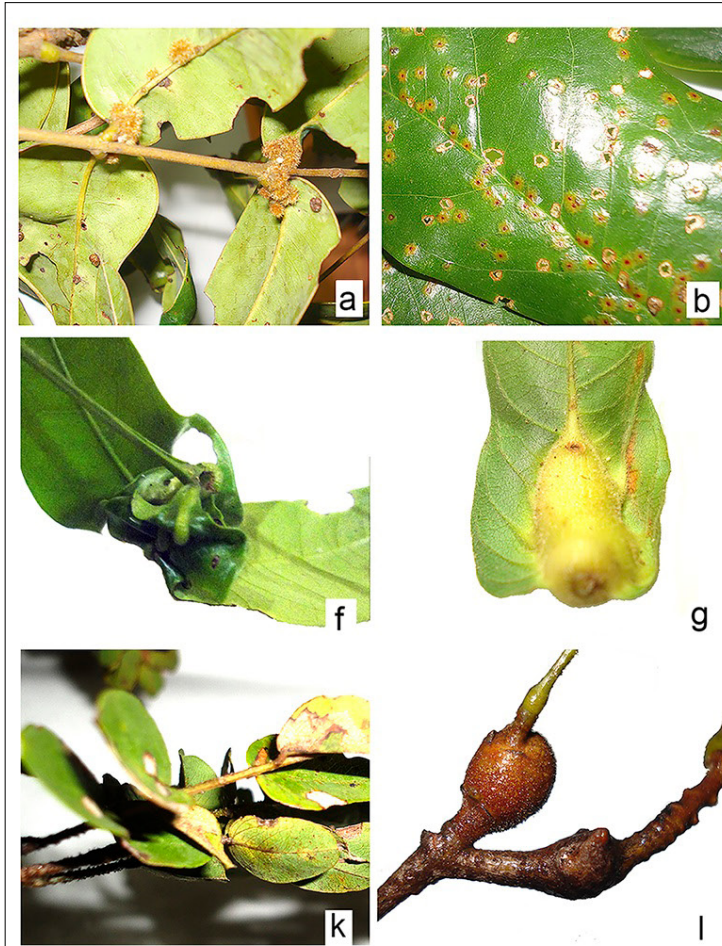

g
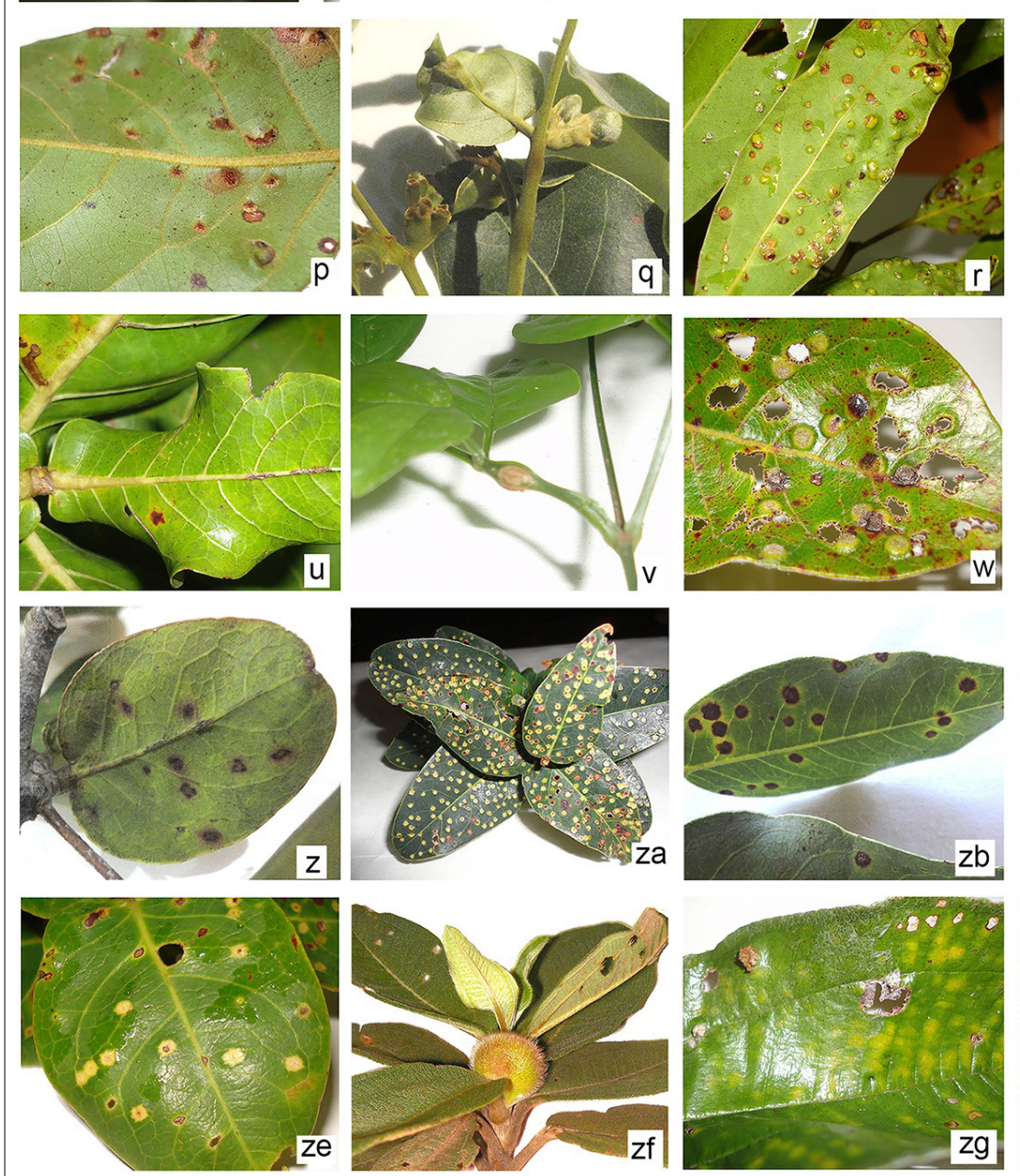
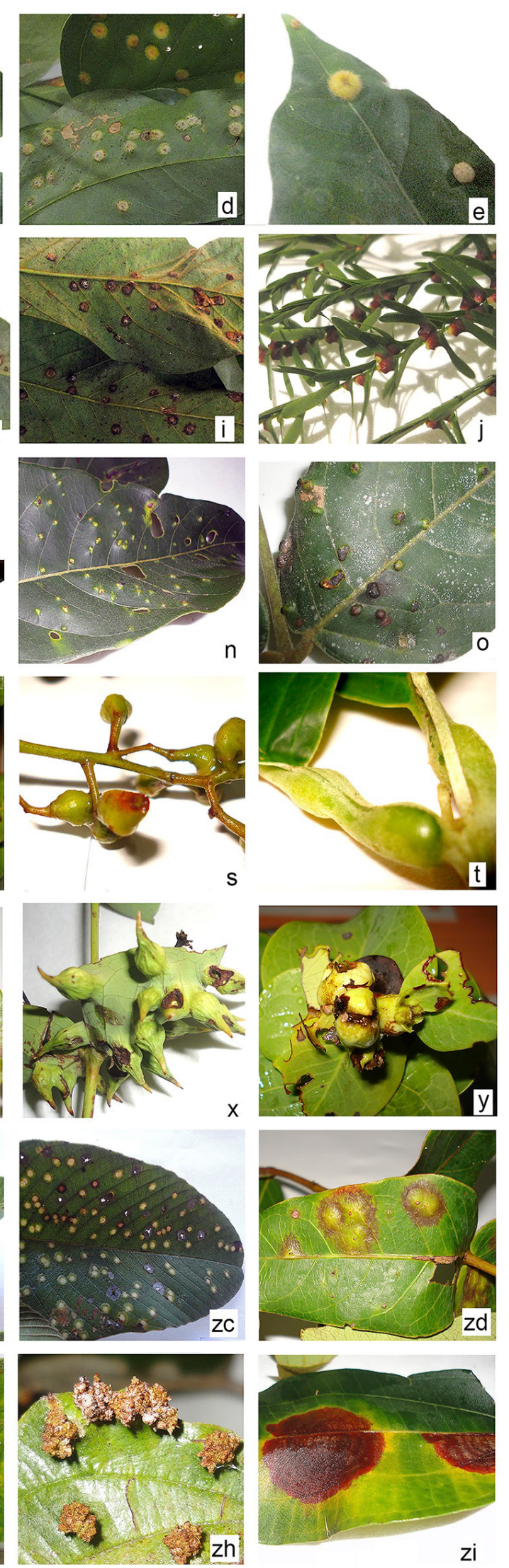

Figure 6. Insect galls of Parque Nacional da Chapada dos Guimarães, Mato Grosso State, Brazil in host plants indicated. Fabaceae. a. Copaifera depilis, b-d. Hymenaea courbaril, e. Inga disticha, f. Inga leiocalycina, g. Inga vera, h. Machaerium sp., i. Ormosia macrophylla, j. Senegalia sp., k-m. Stryphnodendron adstringens, n-p. Tachigali rubiginosa, q. Tachigali subvelutina. Lauraceae. r-s. Aiouea saligna. Malpighiaceae. t. Alicia macrodisca, u. Byrsonima coccolobifolia, v-w. Byrsonima sericea, x. Diplopterys pubipetala, y-ze. Heteropterys cf. coriacea. Melastomataceae. zf. Macairea radula, zg-zh. Miconia albicans, zi. Miconia rubiginosa. 

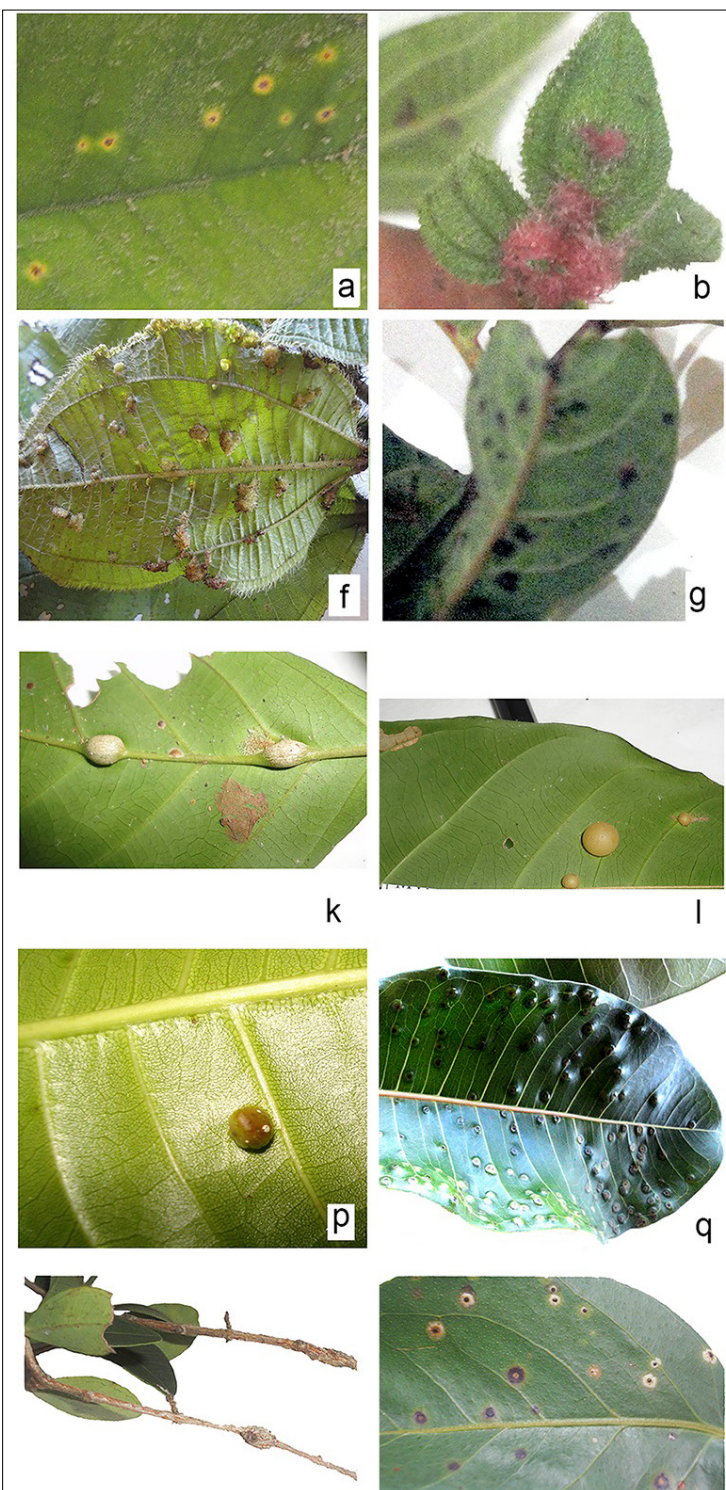

U
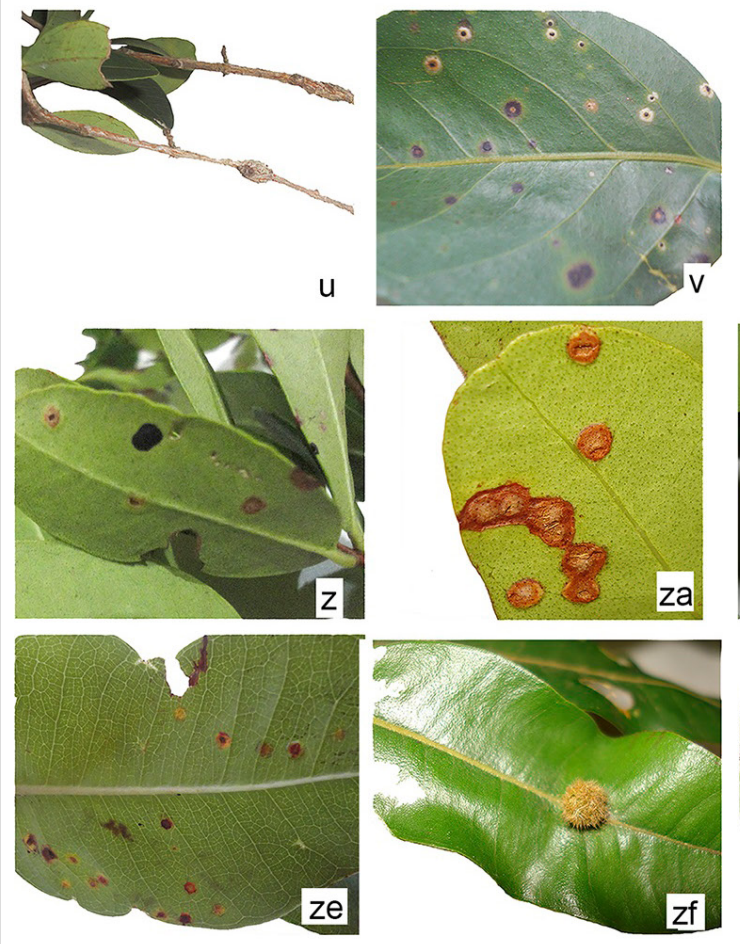
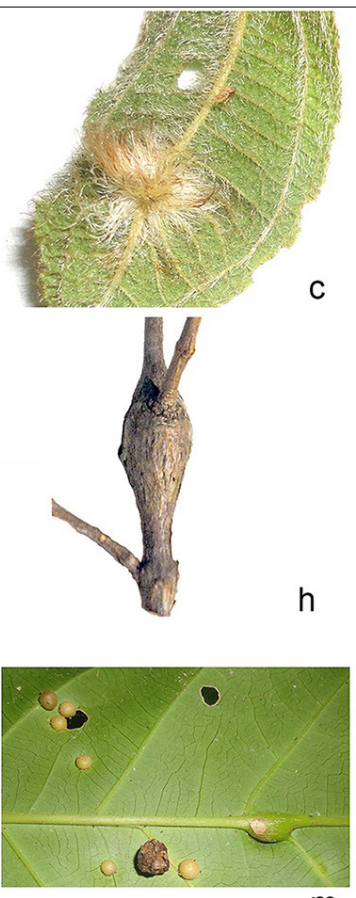

$\mathrm{m}$
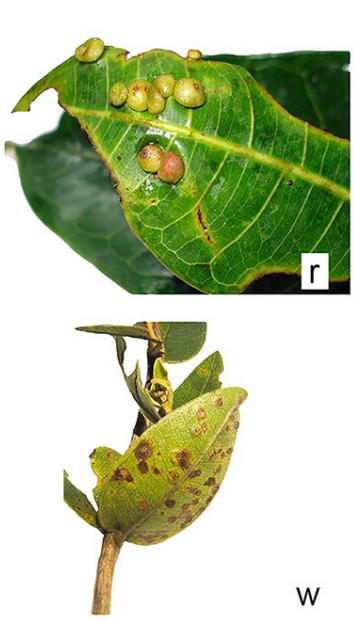

W
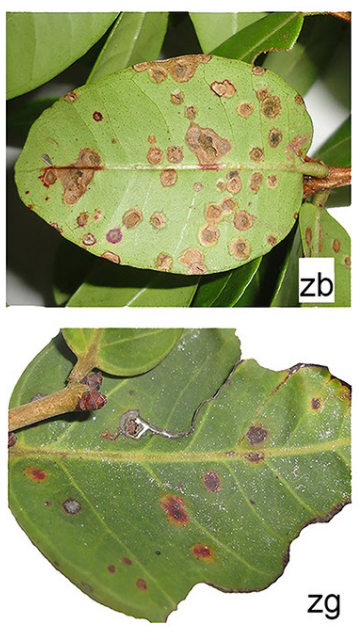
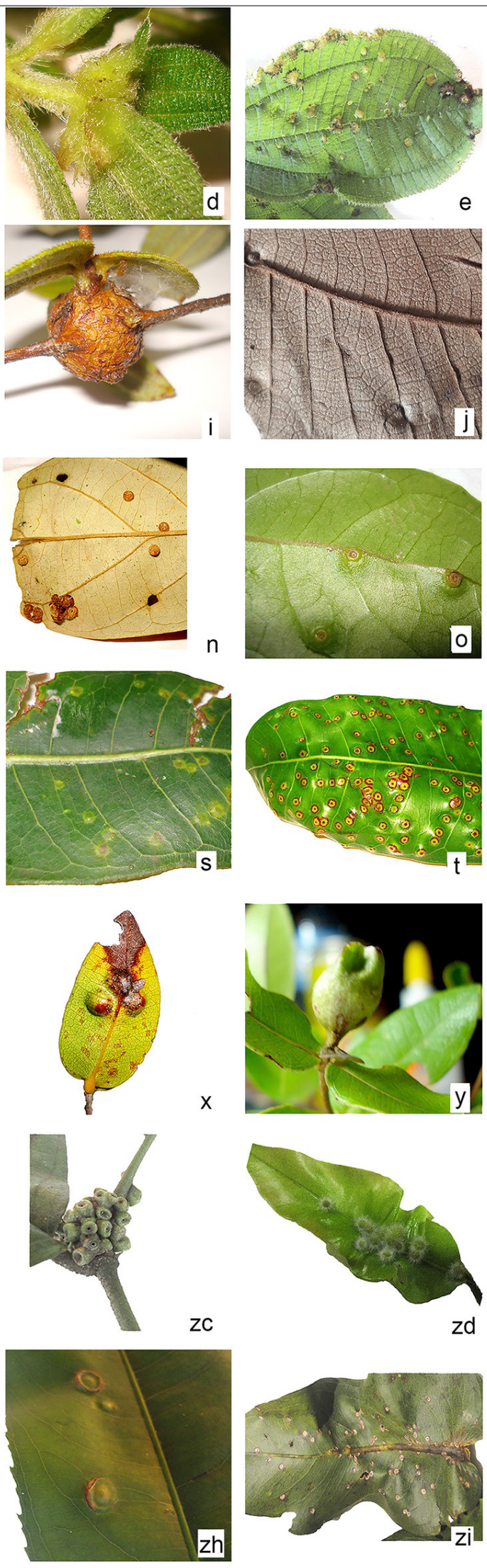

Figure 7. Insect galls of Parque Nacional da Chapada dos Guimarães, Mato Grosso State, Brazil in host plants indicated. Melastomataceae. a-d. Miconia sp. 1, e-f. Miconia sp. 2, g. Mouriri elliptica, h-i. Tibouchina sp. 1, j. Tococa sp. Meliaceae. k-m. Guarea guidonia, n. Guarea macrophylla subsp. spiciflora. Monimiaceae. o. Mollinedia sp. Moraceae. p. Brosimum lactescens, q. Ficus sp. 1, r-t. Ficus sp. 2. Myrtaceae. u. Eugenia punicifolia, v. Eugenia sp., w-y. Myrcia bella, z-za. Myrcia guianensis, zb. Myrcia sp., zc-zf. Myrcia splendens, zg. Myrcia variabilis. Ochnaceae. zh. Ouratea castaneifolia, zi. Ouratea nana. 
Insect galls from Mato Grosso: Cerrado

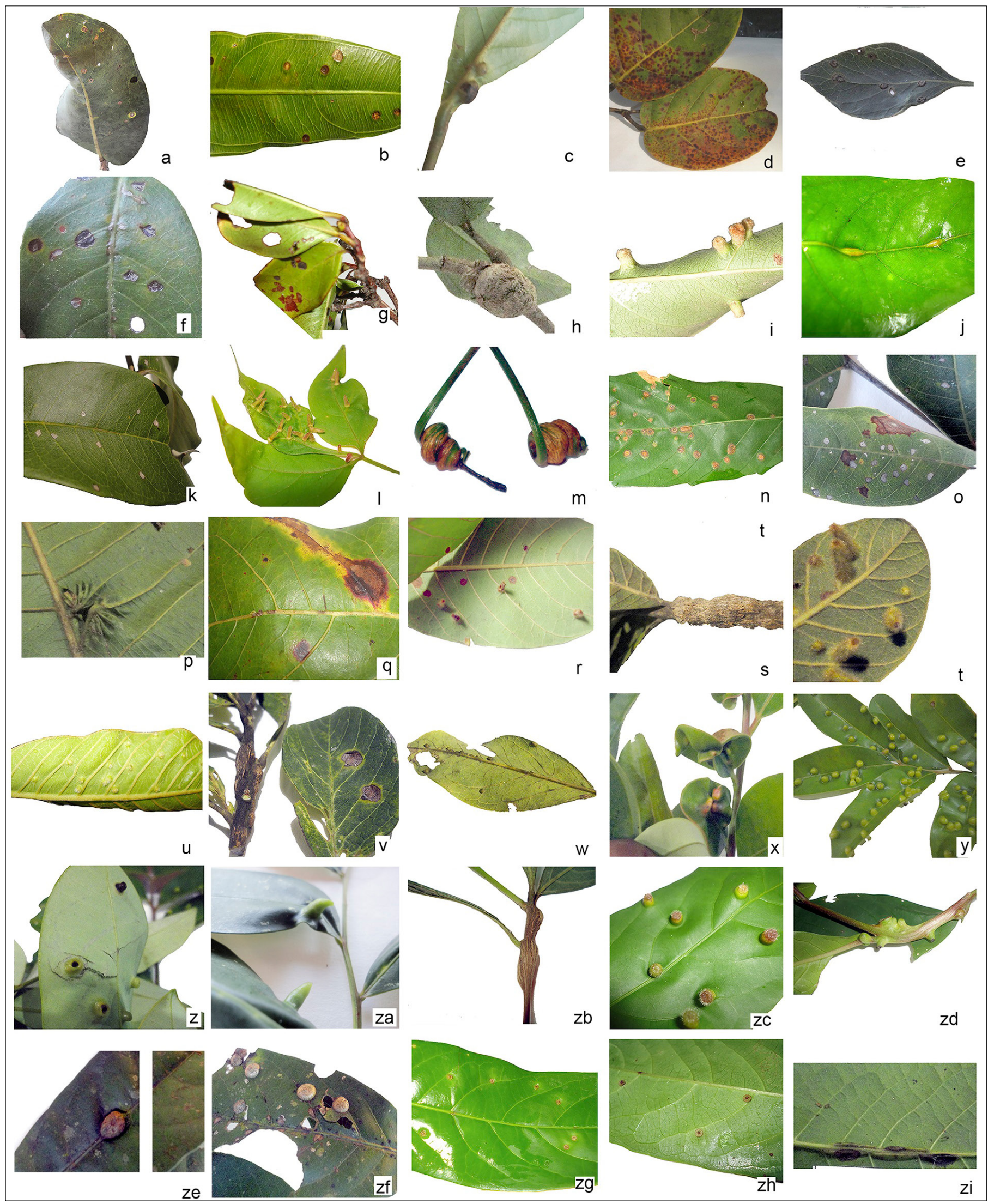

Figure 8. Insect galls of Parque Nacional da Chapada dos Guimarães, Mato Grosso State, Brazil in host plants indicated. Ochnaceae. a. Ouratea nana, b. Ouratea riedeliana. Piperaceae. c. cf. Piper dilatatum. Polygonaceae. d. Coccoloba cujabensis. Proteaceae. e. Roupala montana. Rubiaceae. f. Cordiera myrciifolia, g. Cordiera obtusa. h. Rubiaceae sp. Sapindaceae. i. Matayba guianensis, j. Matayba sp. 1, k. Matayba sp. 2, 1. Serjania caracasana, m. Serjania matogrossensis, n. Serjania sp., o. Talisia subalbens. Sapotaceae. p. Ecclinusa ramiflora, q. Pouteria ramiflora, r-u. Pouteria torta, v. Pouteria sp. 1, w. Pouteria sp. 2. Simaroubaceae. x-za. Simarouba versicolor. Symplocaceae. zb. Symplocos cf. nitens. Siparunaceae. zc-zh. Siparuna guianensis. zi. Siparuna sp. 

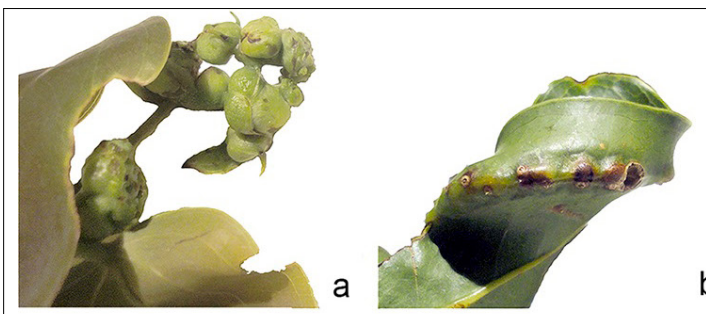

b
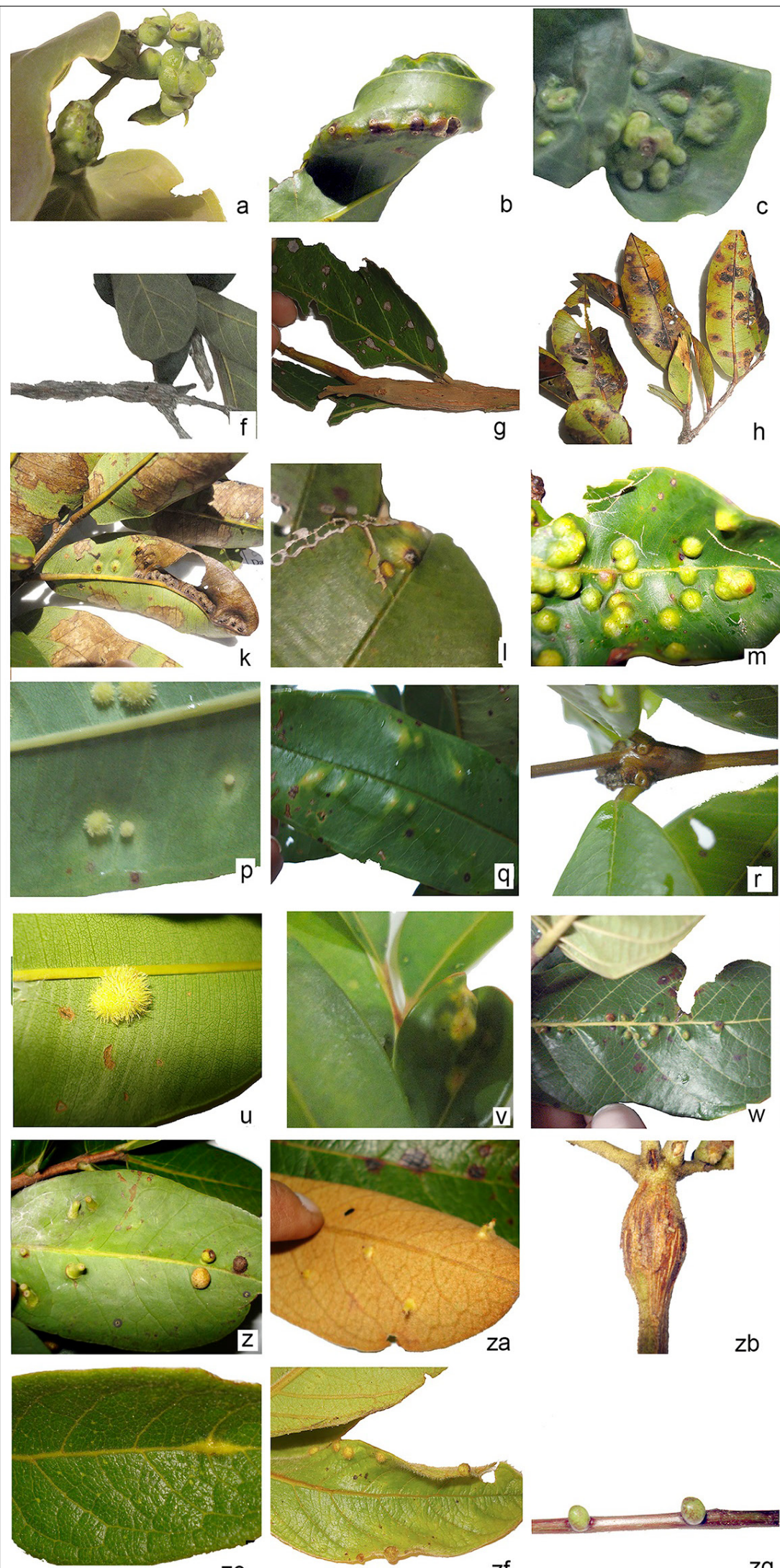

ze

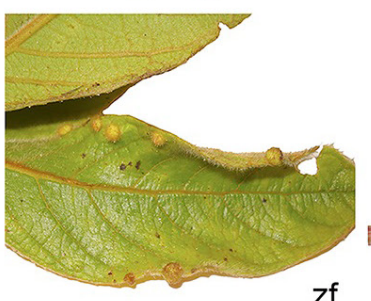

zf
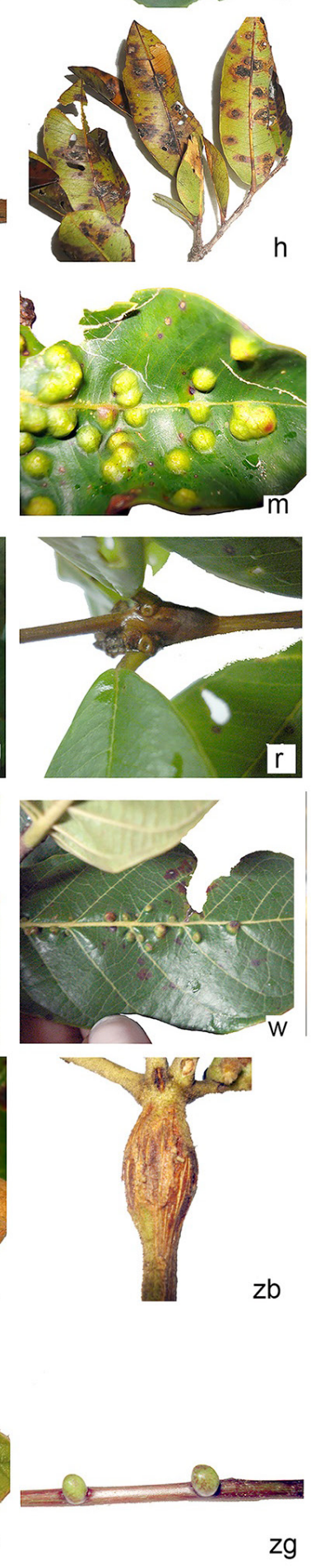
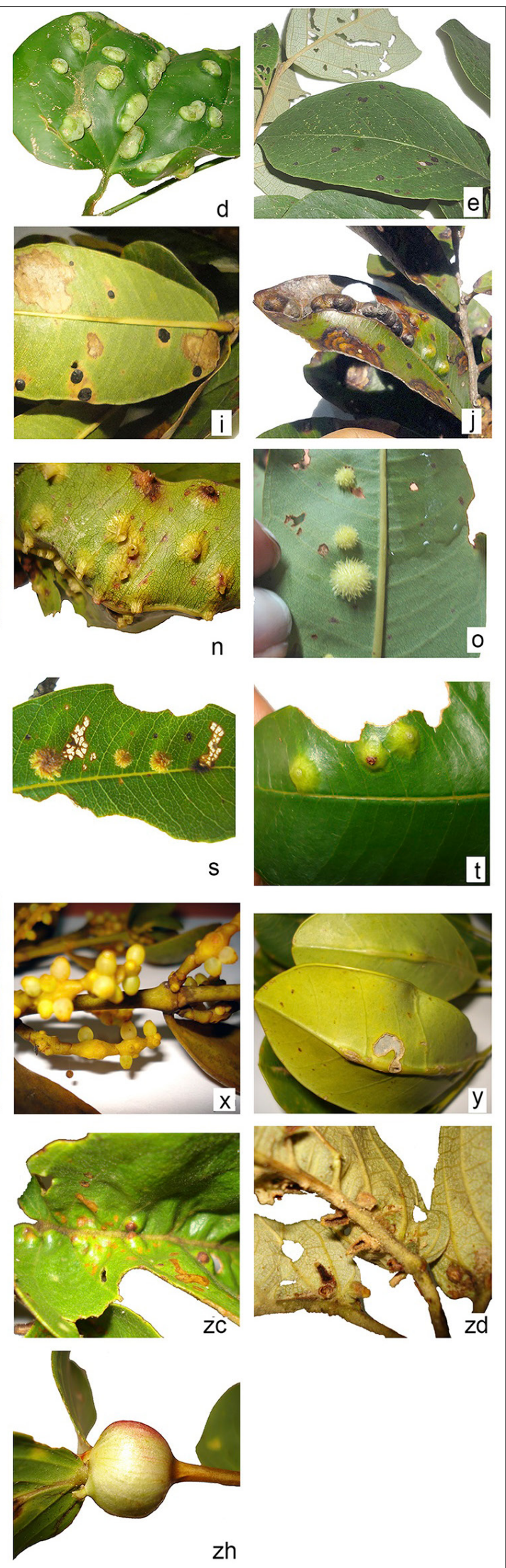

Figure 9. Insect galls of Parque Nacional da Chapada dos Guimarães, Mato Grosso State, Brazil in host plants indicated. Smilacaceae. a-b. Smilax brasiliensis, c-d. Smilax fluminensis. Styracaceae. e-g. Styrax sp. Vochysiaceae. h-s. Qualea parviflora, t-u. Vochysia petraea. Unidentified. v. Unidentified sp. 1, w. Unidentified sp. 2, x. Unidentified sp. 3, y. Unidentified sp. 4, z. Unidentified sp. 5, za. Unidentified sp. 6, zb-zd. Unidentified sp. 7, ze. Unidentified sp. 8, zf. Unidentified sp. 9 , zg. Unidentified sp. 10, zh. Unidentified sp. 11. 

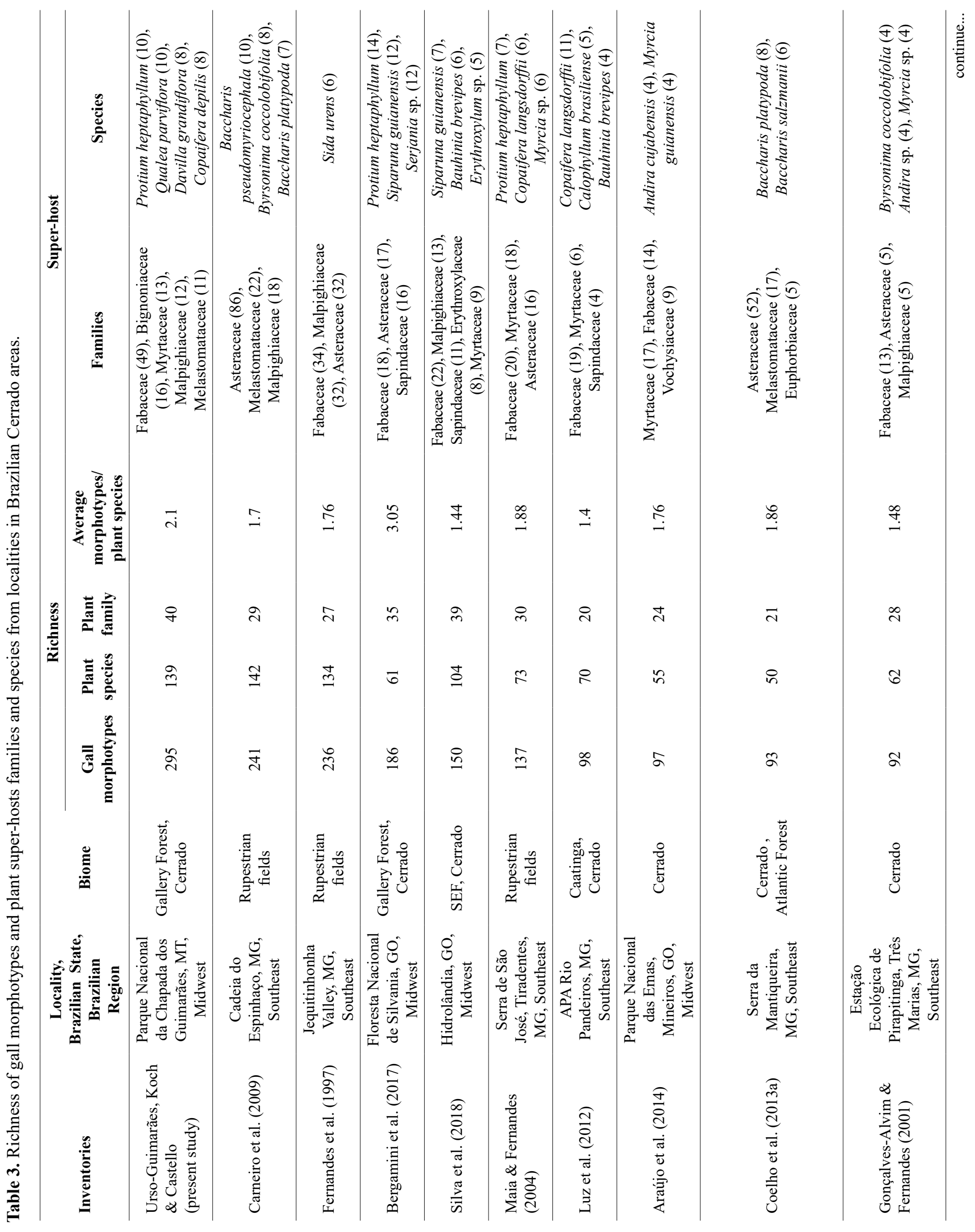


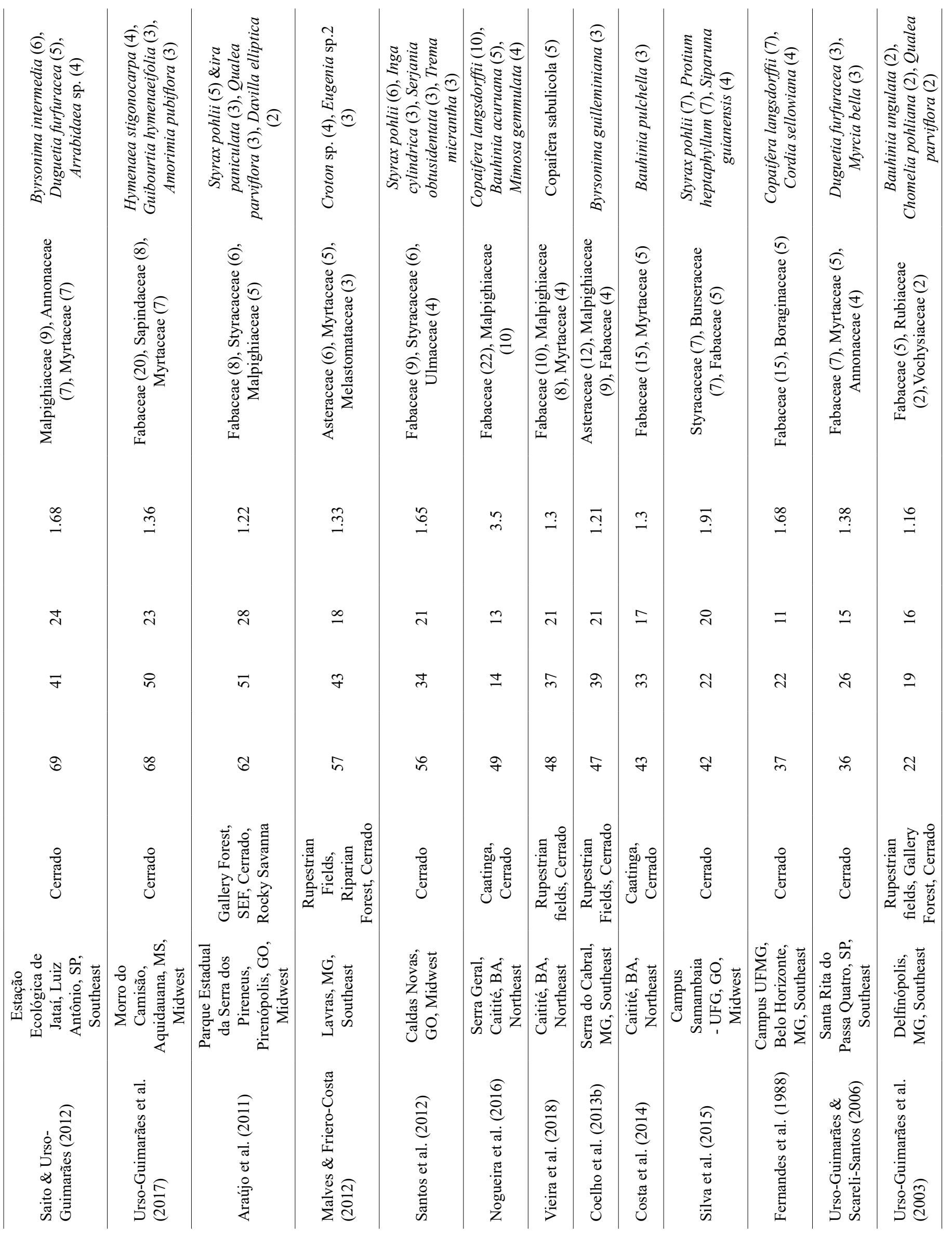


Table 4. Gall makers and associated fauna in galls of Parque Nacional da Chapada dos Guimarães, Mato Grosso, Brazil.

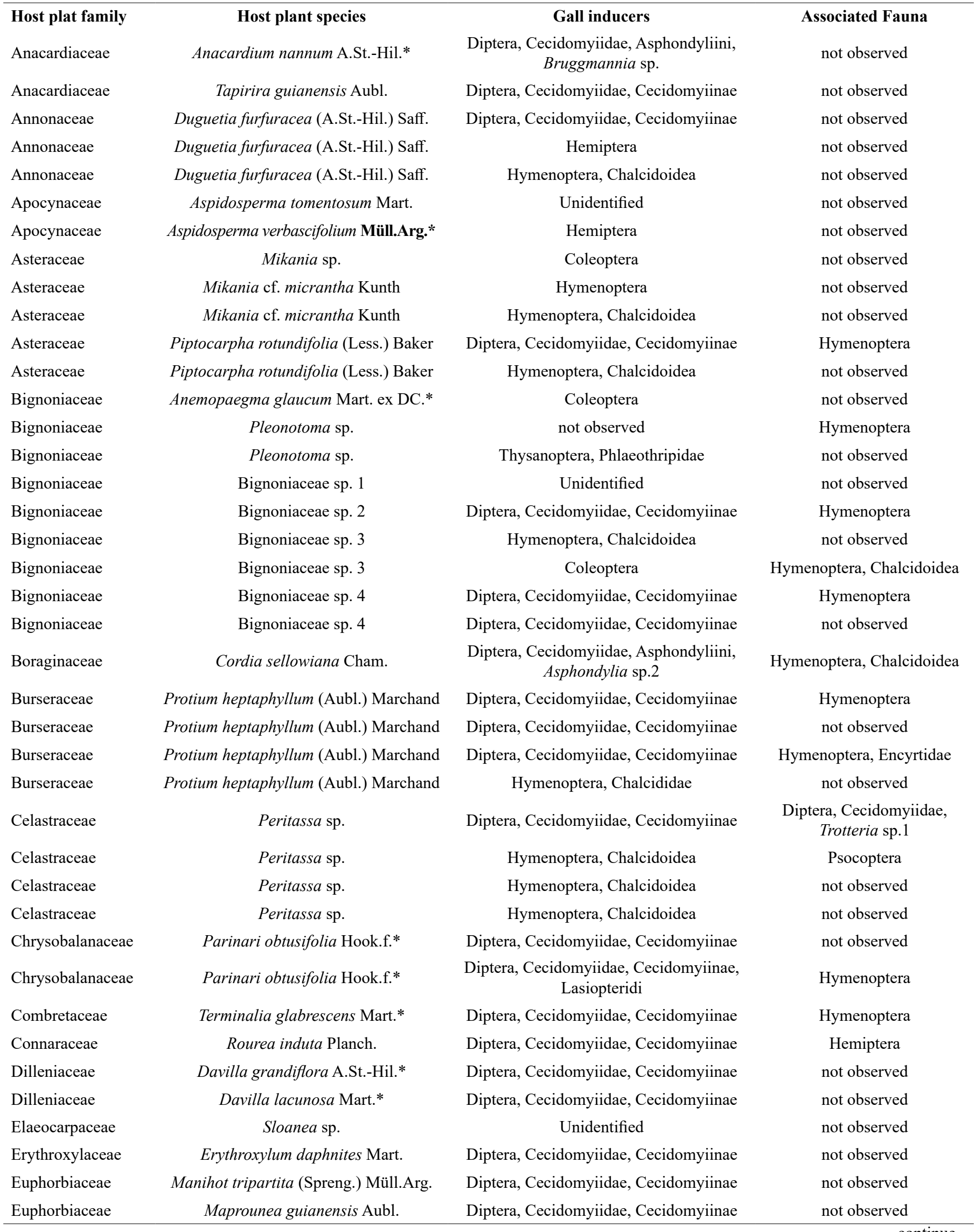


....continuation

\begin{tabular}{|c|c|c|c|}
\hline Fabaceae & Andira cujabensis Benth. & Hymenoptera & not observed \\
\hline Fabaceae & Andira humilis Mart. ex Benth. & $\begin{array}{l}\text { Diptera, Cecidomyiidae, Lopesiini, } \\
\text { Lopesia andira Garcia et al., } 2017\end{array}$ & not observed \\
\hline Fabaceae & $\begin{array}{c}\text { Andira surinamensis (Bondt) Splitg. ex } \\
\text { Amshoff }\end{array}$ & Unidentified & not observed \\
\hline Fabaceae & Andira vermifuga (Mart.) Benth. & $\begin{array}{c}\text { Diptera, Cecidomyiidae, Lopesiini, } \\
\text { Lopesia chapadensis Garcia \& Urso- } \\
\text { Guimarães, } 2018\end{array}$ & not observed \\
\hline Fabaceae & Bauhinia sp. 4 & Unidentified & not observed \\
\hline Fabaceae & Calliandra sp. & Unidentified & Unidentified \\
\hline Fabaceae & Copaifera depilis Dwyer & Unidentified & Unidentified \\
\hline Fabaceae & Hymenaea courbaril L. & Diptera, Cecidomyiidae, Cecidomyiinae & not observed \\
\hline Fabaceae & Inga disticha Benth. & Diptera, Cecidomyiidae, Cecidomyiinae & Hymenoptera, Chalcidoidea \\
\hline Fabaceae & Inga leiocalycina Benth.* & Hemiptera, Cicadelidae & not observed \\
\hline Fabaceae & Ormosia macrophylla Benth.* & Hymenoptera, Chalcidoidea & not observed \\
\hline Fabaceae & $\begin{array}{l}\text { Tachigali subvelutina (Benth.) Oliveira- } \\
\text { Filho* }\end{array}$ & Diptera, Cecidomyiidae, Cecidomyiinae & Thysanoptera \\
\hline Malpighiaceae & $\begin{array}{c}\text { Alicia macrodisca (Triana \& Planch.) } \\
\text { W.R.Anderson* }\end{array}$ & Diptera, Cecidomyiidae, Cecidomyiinae & not observed \\
\hline Melastomataceae & Miconia sp. 1 & Diptera, Cecidomyiidae, Cecidomyiinae & not observed \\
\hline Melastomataceae & Macairea radula (Bonpl.) DC. & $\begin{array}{c}\text { Lepidoptera, Coleophoridae, } \\
\text { Palaeomystella oligophaga Becker \& } \\
\text { Adamski, } 2008\end{array}$ & not observed \\
\hline Melastomataceae & Tibouchina sp. & Unidentified & not observed \\
\hline Meliaceae & Guarea guidonia (L.) Sleumer & Hymenoptera, Chalcidoidea & not observed \\
\hline Moraceae & Ficus sp. 2 & Coleoptera & not observed \\
\hline Myrtaceae & Myrcia guianensis (Aubl.) DC. & Hymenoptera, Chalcidoidea & not observed \\
\hline Myrtaceae & Myrcia splendens (Sw.) DC. & Diptera, Cecidomyiidae, Cecidomyiinae & not observed \\
\hline Piperaceae & cf. Piper dilatatum Rich. & Hymenoptera, Chalcidoidea & not observed \\
\hline Rubiaceae & Rubiaceae sp. & Hymenoptera, Chalcidoidea & not observed \\
\hline Sapindaceae & Serjania caracasana (Jacq.) Willd. & $\begin{array}{c}\text { Diptera, Cecidomyiidae, Dasineurini, } \\
\text { Dasineura } \mathrm{sp} .\end{array}$ & not observed \\
\hline Sapindaceae & $\begin{array}{c}\text { Serjania matogrossensis Ferrucci \& } \\
\text { Acev.-Rodr.* }\end{array}$ & Diptera, Cecidomyiidae, Cecidomyiinae & not observed \\
\hline Sapindaceae & Matayba guianensis Aubl. & $\begin{array}{l}\text { Diptera, Cecidomyiidae,Lopesiini, } \\
\text { Lopesia mataybae Garcia \& Urso- } \\
\text { Guimarães, } 2018\end{array}$ & not observed \\
\hline Sapotacae & Pouteria torta (Mart.) Radlk. & $\begin{array}{c}\text { Diptera, Cecidomyiidae, Youngomyia } \\
\text { matogrossensis Proença \& Maia, } 2019\end{array}$ & not observed \\
\hline
\end{tabular}


....continuation

\begin{tabular}{|c|c|c|c|}
\hline Sapotaceae & Pouteria torta (Mart.) Radlk. & $\begin{array}{l}\text { Diptera, Cecidomyiidae, Asphondyliini, } \\
\text { Stephomyia sp. }\end{array}$ & $\begin{array}{l}\text { Diptera, Cecidomyiidae, } \\
\text { Trotteria } \mathrm{sp} .2\end{array}$ \\
\hline Simaroubaceae & Simarouba versicolor A.St.-Hil.* & Coleoptera, Curculionidae, Scolytinae & not observed \\
\hline Simplocaceae & Symplocos cf. nitens (Pohl) Benth.* & Diptera, Cecidomyiidae, Cecidomyiinae & not observed \\
\hline Siparunaceae & Siparuna guianensis Aubl. & $\begin{array}{l}\text { Diptera, Cecidomyiidae, Asphondyliini, } \\
\text { Asphondylia sp.1 }\end{array}$ & not observed \\
\hline Siparunaceae & Siparuna guianensis Aubl. & Thysanoptera, Phlaeothripidae & Coleoptera, Curculionidae \\
\hline Smilacaceae & Smilax fluminensis Steud. & Unidentified & Diptera, Phoridae \\
\hline Styracaceae & Styrax sp. & Hymenoptera, Chalcidoidea, Pteromalidae & not observed \\
\hline Vochysiacece & Qualea parviflora Mart & Diptera, Cecidomyiidae, Cecidomyiinae & not observed \\
\hline Vochysiacece & Qualea parviflora Mart & Diptera, Cecidomyiidae, Cecidomyiinae & not observed \\
\hline Unidentified & Unidentified sp. 10 & Diptera, Cecidomyiidae, Cecidomyiinae & not observed \\
\hline Unidentified & Unidentified sp. 11 & Coleoptera & not observed \\
\hline
\end{tabular}

other phytophysiognomies than Cerrado strict sensu, our results allow us to state that the Parque Nacional da Chapada dos Guimarães harbors the highest number of gall morphotypes and the second-highest gall morphotypes average per plant species found in the Cerrado hitherto (Araújo et al. 2019, Cintra et al. 2020). The number of morphotypes (295) and the average of morphotypes per plant species (2.1) are comparable with those found in the Parque Nacional de Silvania (GO) (Bergamini et al. 2017), with similar phytophysiognomies sampled (Gallery Forest and Cerrado strict sensu). These authors found 186 gall morphotypes and an average of 3.0 gall morphotypes per species, representing the highest average recorded in the Cerrado Biome (Bergamini et al. 2017). A similar pattern was found in studies conducted in Campos Rupestres (rupestrian grasslands) in the Cadeia do Espinhaço (Carneiro et al. 2009) and in the Vale do Rio Jequitinhonha (Fernandes et al. 1997) (both in Minas Gerais State), with 241 and 236 gall morphotypes, respectively and an average of 1.7 morphotypes per species each.

Our results corroborate the hypothesis that environmental stress (Fernandes \& Price 1988) would justify the high richness of gall morphotypes in these phytophysiognomies. Indeed, considering that gall morphotypes are extended phenotypes of their inducers (Abrahamson \& McCrea 1986), it also justifies gall makers' high richness in scleromorphic vegetation. The plants of practically all phytophysiognomies in Cerrado have adaptations to soil poverty and hydric stress, recognized in high concentrations of defense compounds, especially tannins. This higher concentration of chemical compounds provides the galls inducers defense against predators and pathogens (Fernandes \& Price 1992). Allied to this, manipulating the nutritional resources in very young vegetable tissue (Fernandes et al. 2011) allows the gallers larvae access to nutrients inaccessible to other herbivores.

Fabaceae, Bignoniaceae, Melastomataceae, Myrtaceae, Burseraceae, Malpighiaceae, and Vochysiaceae are the richer families in species in the Parque Nacional da Chapada dos Guimarães, which corroborates in part the hypothesis of the predominance of gall morphotypes in the families with the most remarkable species richness (Southwood 1960, 1961,
Santos-Silva \& Araújo 2020). Also confirm the predominance of these families in the data compiled by Cintra et al. (2020). Fabaceae is among the five richest families in gall morphotypes in 20 of the 22 studies in Cerrado phytophysiognomies, Myrtaceae in 11, and Malpighiaceae in 10 (Araújo et al. 2019). On the other hand, Vochysiaceae is a super host family case because, in just two species, we found a high number of morphotypes (12), contributing to increasing the total number of gall morphotypes in the sampled area. This family was also mentioned as a super host in an area of Cerrado in Goiás state (Araújo 2011). Bignoniaceae was referred to as a rich family in gall morphotypes in Pantanal (Julião et al. 2002; Urso-Guimarãeset al. 2017), but it is among the super host families in the Cerrado for the first time. In the compilation of 32 areas of Cerrado, Cintra et al. (2020) found 20 gall morphotypes against 16 morphotypes found in this study. These results may be related to the fact that all Bignoniaceae species sampled in this study are climbing plants, which are not frequently sampled in studies about galling insects. It shows the importance of sampling all vegetation strata to understand the galling insects' distribution in their hosts.

From the richest plant genera in gall morphotypes found in Parque Nacional da Chapada dos Guimarães, Andira Lam. and Myrcia DC. are richer in species, and Davilla Vand. and Protium Burm.f. are super host species (Table 3). Myrcia appears as one of the richest genera in the Cerrado records in Cintra et al. (2020). But Andira, Davilla, and Protium are referred as morphotype richest genera for the first time to Cerrado biome.

Protium heptaphyllum (Aubl.) Marchand, Qualea parviflora Mart, Davilla grandiflora A.St.-Hil. and Copaifera depilis Dwyer were the richest host species in the studied area (Table 3 ), being $D$. grandiflora reported as super host of gall morphotypes for the first time.

Leaves are the most abundant resource in any biome. The scleromorphic plants in the Cerrado biome have low leaf abscission rates (Fernandes \& Price 1988; Price et al. 1998; Cuevas-Reyes et al. 2004), so it is natural that most galls occurred on leaves. The shapes more common, lenticular and globoid, are predominant because they 
favor the reduction of water loss, mainly on leaf galls, compared to more bulky shapes such as cylindrical and conical. Together with the color green and glabrous galls, these predominant characteristics are a pattern also found in precedent surveys in Cerrado phytophysiognomies (Araújo et al. 2019).

The Cecidomyiidae was the predominant family among the gall inducers, as found in surveys worldwide (Espírito-Santo \& Fernandes 2007).

All plant species are new as host to insect galls to the state of Mato Grosso, except for Andira cujabensis Benth., A. vermifuga (Mart.) Benth., Matayba guianensis Aubl. (Garcia et al. 2017, Garcia \& UrsoGuimarães 2018) and Pouteria torta (Mart.) Radlk. (Proença \& Maia 2019). Eight percent of the 84 genera found in this inventory are new records as a host plant for insect galls, and $27 \%$ of the total host plant species sampled in Parque Nacional da Chapada dos Guimarães are new as host for galls. Among the new registers, Bernardia similis Pax $\&$ K.Hoffm and Ormosia macrophylla Benth., also are registered for the first time in the flora of Mato Grosso State (Flora do Brasil 2020). That reinforces the importance of multidisciplinary studies like this, founding new points of occurrence for plant species and the associated fauna.

The two species classified as threatened, Vochysia petraea Warm. and Talisia subalbens (Mart.) Radlk., are endemic of Cerrado in Mato Grosso State (Shimizu et al. 2020, Acevedo-Rodríguez 2015). Currently, the state is one of Brazil's agricultural frontiers to soybean plantation areas, meaning that both plant species and their interactions (e.g., galls and associated fauna) are also threatened with extinction.

Studies like this collaborate to increase the knowledge about a rich and undescribed fauna. This fauna begins to be documented from its extended phenotype - the gall - which remains on the host plant even after the emergence of the galler. The taxonomic studies' continuity in the areas registered here is fundamental to identify and describe the inducers and the associated fauna. Before the SISBIOTA - Diptera Brasil Program (2010-2015), this study is part, only two species of Cecidomyiidae, the principal inducer of galls in the world, had the occurrence registered in this Mato Grosso State, Termitomastus leptoproctus Silvestri, 1901 and Asphondylia tuiuiu Urso-Guimarães \& Amorim, 2002. Currently, four new species found in this survey have been described - Lopesia andirae Garcia et al., 2017, L. chapadensis Garcia \& Urso-Guimarães, 2018, L. mataybae Garcia \& Urso-Guimarães, 2018, and Youngomyia matogrossensis Proença \& Maia, 2019. Another five are under the description (Asphondylia spp., Bruggmannia sp., Dasineura sp. and Stephomyia sp.). Even with the efforts addressed during this period, gall inducers' fauna remains poorly known because they are highly diversified. More investigation focused on finding all stages of the life cycle of gall morphotypes documented in this study is necessary to understand this fauna's richness, including the other insects from the associated guild.

\section{Acknowledgements}

MVUG acknowledges the Conselho Nacional de Desenvolvimento Científico e Tecnológico (Proc. CNPq 563256/2010-9) and Fundação de Amparo à Pesquisa do Estado de São Paulo (Proc. FAPESP 10/52314-0) for the support to the field works under the SISBIOTA - Diptera Brasil Program. The authors also thank J. Semir - in memorian, J. Tamashiro, G.H. Shimizu, A. F. Versiane and A.V. Scatigna (IB/UNICAMP), R.B.
Pinto (UFG) and M. Monge (UFU) for invaluable help in plant species identification.

\section{Author Contributions}

Dr. Maria Virginia Urso-Guimarães - Substantial contribution in the concept and design of the study, data collection, data analysis and interpretation, manuscript preparation, critical revision, adding intellectual content; Dr. Ingrid Koch and Dr. Ana Carolina Devides Castello - Substantial contribution in the data analysis and interpretation, manuscript preparation, critical revision, adding intellectual content.

\section{Conflicts of Interest}

The authors declare that they have no conflict of interest related to the publication of this manuscript.

\section{References}

ABRAHAMSON, W.G. \& McCREA, K.D. 1986. The impacts of galls and gall makers on plants. Proc. Entomol. Soc. Wash. 88:364-367.

ACEVEDO-RODRÍGUEZ, P. 2015. Talisia in Lista de Espécies da Flora do Brasil. Jardim Botânico do Rio de Janeiro. http://floradobrasil.jbrj.gov.br/ jabot/floradobrasil/FB32757 (last access on 05/04/ 2021).

ARAÚJO, W.S. 2011. Can host plant richness be used as a surrogate for galling insect diversity? Trop. Conserv. Sci. 4:420-427.

ARAÚJO, W.S., SANTOS, B.B. \& GOMES-KLEIN, V.L. 2011. Insect galls from Serra dos Pireneus, GO, Brazil. Biota Neotrop. 11(2):357-365. http:// dx.doi.org/10.1590/S1676-06032011000200034 (last access on 20/12/2020).

ARAÚJO, W.S., SOBRAL, F.L. \& MARACAHIPES, L. 2014. Insect galls of the Parque Nacional das Emas (Mineiros, GO, Brazil). Check List. 10(6): 1445-1451.

ARAÚJO, W.S., FERNANDES, G.W. \& SANTOS, J.C. 2019. An overview of inventories of gall-inducing insects in Brazil: looking for patterns and identifying knowledge gaps. An. Acad. Bras. Ciênc. 91(1):e20180162. http:// dx.doi.org/10.1590/0001-3765201920180162 (last access on 20/12/2020).

ARAÚJO W.S., URSO-GUIMARÃES M.V., MENDONÇA M..S. \& SANTOS J.C. 2021. Sampling Galls and Galling Arthropods. In Measuring Arthropod Biodiversity (J.C.Santos \& G.W. Fernandes, eds). Springer, Cham, p. 403-437.

BERGAMINI, B.A.R., BERGAMIN, L.L., SANTOS, B.B. \& ARAÚJO. W.S. 2017. Occurrence and characterization of insect galls in the Floresta Nacional de Silvânia, Brazil. Pap. Avulsos Zool. 57(32):413-431.

BUENO, M., DEXTER, K., PENNINGTON, R., PONTARA, V., NEVES, D., RATTER, J. \& OLIVEIRA-FILHO, A. 2018. The environmental triangle of the Cerrado domain: ecological controls driving shifts in tree species composition between savannas and forests. J. Ecol. 106(5):2109-2120.

CARNEIRO, M.A.A., BORGES, R.A.X., ARAÚJO, A.P.A. \& FERNANDES, G.W. 2009. Insetos indutores de galhas da porção sul da Cadeia do Espinhaço, Minas Gerais, Brasil. Rev. Bras. Entomol. 53(4):570-592.

CINTRA, F.C.F., ARAUJO, W.S., MAIA, V.C., URSO-GUIMARÃES, M.V., VENÂNCIO, H., ANDRADE, J. F., CARNEIRO, M.A.A., ALMEIDA, W.R., SANTOS, J.C. 2020. Plant galling insect interactions: a data set of host plants and their gall inducing insects for the Cerrado. Ecology. 101:e03149.

COELHO, M.S., CARNEIRO, M.A.A., BRANCO, C.A. \& FERNANDES, G.W. 2013a. Gall-inducing insects from Serra do Cabral, Minas Gerais, Brazil. Biota Neotrop. 13(3):102-109. http://dx.doi.org/10.1590/S167606032013000300013 (last access on 20/12/2020)

COELHO, M.S., CARNEIRO, M.A.A., BRANCO, C.A., BORGES, R.A.X. \& FERNANDES, G.W. 2013b. Gall-inducing insects from Campos de Altitude, Brazil. Biota Neotrop. 13(4): 139-151. http://dx.doi.org/10.1590/ S1676-06032013000400015 (last access on 20/12/2020). 
COSTA, E.C., CARVALHO-FERNANDES, S.P. \& SANTOS-SILVA, J. 2014 Galhas de insetos em uma área de transição caatinga-cerrado no Nordeste do Brasil. Sitientibus, Sér. Ciênc. Biol. 14:1-9.

CUEVAS-REYES, P., QUESADA, M., HANSON, P., DIRZO, R. \& OYAMA, K. 2004. Diversity of gall-inducing insects in a Mexican tropical dry forest: the importance of plant species richness, life-forms, host plant age and plant density. J. Ecol. 92:707-716.

ESPÍRITO-SANTO, M.M. \& FERNANDES, G.W. 2007. How many species of gall-inducing insects are there on earth, and where are they? Ann. Entomol. Soc. Am. 100(2):95-99.

FERNANDES, G.W. \& PRICE, P.W. 1988. Biogeographical gradients in galling species richness: tests of hypotheses. Oecologia. 76:161-167.

FERNANDES, G.W. \& PRICE, P.W. 1992. The adaptive significance of insect gall distribution: Survivorship of species in xeric and mesic habitats. Oecologia. 90:14-20.

FERNANDES, G.W., TAMEIRÃO-NETO, E. \& MARTINS, R. P. 1988 Ocorrência e caracterização de galhas entomógenas na vegetação do Campus Pampulha da Universidade Federal de Minas Gerais. Rev. Bras. Zool. 5:11-29.

FERNANDES, G.W., ARAÚJO, R.C., ARAÚJO, S.C., LOMBARDI, J.A., PAULA, A.S., LOYOLA-JÚNIOR, R. \& CORNELISSEN, T.G. 1997. Insect-galls from savanna and rocky fields of the Jequitinhonha valley, Minas Gerais, Brazil. Naturalia. 22:221-244.

FERNANDES, G.W., CARNEIRO, M.A.A. \& ISAIAS, R.M.S. 2011. Gallinducing insects: from anatomy to biodiversity. In Insect bioecology and nutrition for integrated pest management (Panizzi \& Parra eds.). CRC Press, Boca Raton, p. 369-395.

FLORA DO BRASIL 2020. 2020. Flora do Brasil 2020. Jardim Botânico do Rio de Janeiro. http://floradobrasil.jbrj.gov.br/ (last access on 20/12/2020).

GARCIA, C.A. \& URSO-GUIMARÃES, M.V. 2018. Three new species of Lopesia Rübsaamen (Diptera: Cecidomyiidae) from Brazil. Fla. Entomol. 101:203-211.

GARCIA, C.A., LIMA, V.P., CALADO, D.C. \& URSO-GUIMARÃES, M.V 2017. New species of Lopesia Rübsaamen (Diptera: Cecidomyiidae) associated with Andira humilis Mart. ex Benth. (Fabaceae). Rev. Bras. Entomol. 61:239-242.

GONÇALVES-ALVIM, S.J. \& FERNANDES, G.W. 2001. Comunidades de insetos galhadores (Insecta) em diferentes fisionomias do cerrado em Minas Gerais, Brasil. Rev. Bras. Zool. 18:289-305.

JULIÃO, G.R., AMARAL, M.E. \& FERNANDES, G.W. 2002. Galhas de insetos e suas plantas hospedeiras no Pantanal Sul Mato Grossense. Naturalia. 27:47-74.

LUZ, G.R., FERNANDES, G.W., SILVA, J.O., NEVES, F.S. \& FAGUNDES, M. 2012. Insect galls in xeric and mesic habitats in a Cerrado-Caatinga transition in northern Minas Gerais, Brazil. Neotrop. Biol. Conserv. 7:171-187.

MAIA, V.C. \& FERNANDES, G.W. 2004. Insect galls from Serra de São José (Tiradentes, MG, Brazil). Braz. J. Biol. 64:423-445.

MALVES, K. \& FRIEIRO-COSTA, A. 2012. List of plants with galls induced by insects from the UNILAVRAS/Boqueirão Biological Reserve, Ingaí, state of Minas Gerais, Brazil. Check List. 8:426-431.

MARENGO, J.A., CUNHA, A.P., CUARTAS, L.A, LEAL, K.R.D., BROEDEL, E, SELUCHI, M.E., MICHELIN, C.M, BAIÃO, C.F.D.P., ÂNGULO, E.C., ALMEIDA, E.K., KAZMIERCZAK, M.L., MATEUS, N.P.A., SILVA, R.C. \& BENDER, F. 2021. Extreme Drought in the Brazilian Pantanal in 2019-2020: Characterization, Causes, and Impacts. Front. water. 3:e639204. https://doi.org/10.3389/frwa.2021.639204.

NOGUEIRA, R.M., COSTA, E.C., CARVALHO-FERNANDES, S.P. \& SANTOS-SILVA, J. 2016. Insect galls from Serra Geral, Caetité, BA, Brazil. Biota Neotrop. 16(1):e20150035. http://dx.doi.org/10.1590/16760611-BN-2015-0035 (last access on 20/12/2020).
PRICE, P., FERNANDES, G.W., LARA, A.C.F., BRAWN, J., GERLING, D., BARRIOS, H., WRIGHT, M.G., RIBEIRO, S.P. \& ROTHCLIFF, N. 1998. Global patterns in local number of insect galling species. J. Biogeogr. 25:581-591.

PROENÇA, B. \& MAIA, V.C. 2019. A new species of Youngomyia Felt from Brazil and new morphological data on Youngomyia pouteriae Maia (Insecta, Diptera, Cecidomyiidae. Rev. Bras. Entomol. 63:130-135.

RIBEIRO, J.F. \& WALTER, B.M.T. 2008. As Principais Fitofisionomias do Bioma Cerrado. In Cerrado: ecologia e flora v.2. (S.M. Sano, S.P. Almeida, \& J.F. Ribeiro, eds.). Embrapa-Cerrados, p. 152-212.

RUSSO, G., ALENCAR, A., RIBEIRO, V., AMORIM, C., SHIMBO, J., LENTI, F. \& CASTRO, I. 2018. IPAM Amazônia. Cerrado: A contribuição da savana brasileira para emissões de GEE e soluções climáticas. https://ipam.org. br/wp-content/uploads/2018/12/Policy-Brief-Cerrado-COP24-pt.pdf (last access on 20/12/2020).

SAITO, V. S. \& URSO-GUIMARÃES, M.V. 2012. Characterization of galls, insect galls and associated fauna of Ecological Station of Jataí (Luiz Antônio, SP). Biota Neotrop. 12(3):99-107. http://dx.doi.org/10.1590/ S1676-06032012000300011 (last access on 20/12/2020).

SANTOS, B.B., RIBEIRO, B.A., SILVA, T.M. \& ARAÚJO, W.S. 2012. Galhas de insetos em uma área de cerrado sentido restrito na região semi-urbana de Caldas Novas (Goiás, Brasil). Rev Bras Biocienc. 10:439-445.

SANTOS-SILVA, J. \& ARAÚJO, T.J. 2020. Are Fabaceae the principal superhosts of galls in Brazil? An. Acad. Bras. Cienc. 92(2): e20181115. https:// doi.org/10.1590/0001-3765202020181115.

SHIMIZU, G.H., SOUZA, L.F., GONÇALVES, D.J.P. \& FRANÇA, F. 2020. Vochysiaceae in Flora do Brasil 2020. Jardim Botânico do Rio de Janeiro. http:// floradobrasil.jbrj.gov.br/reflora/floradobrasil/FB33327 (last access in 05/04/2021).

SILVA, T.M., ARAÚJO, W.S. \& SANTOS, B.B. 2015. Ocorrência e caracterização de galhas de insetos em um fragmento de mata semicaducifólia do Câmpus Samambaia, Goiânia, GO, Brasil. Rev. Biol. Trop.12:26-38.

SILVA, E.C., SANTOS, B.B. \& ARAÚJO, W.S. 2018. Insect gall occurrence in savanna and forest remnant sites of Hidrolândia, GO, Brazil Central Pap. Avulsos Zool. 58:e20185804. https://doi.org/10.11606/18070205/2018.58.04

SOUTHWOOD, T.R.E. 1960. The abundance of the Hawaiian trees and the number of their associated insect species. Proc. Hawaii. Entomol. Soc. 17:299-303.

SOUTHWOOD, T.R.E. 1961. The number of insect associated with various trees. J Anim Ecol. 30:1-8.

URSO-GUIMARÃES, M.V., CASTELO, A.C.D., KATAOKA, E. \& KOCH, I. 2017. Characterization of entomogen galls from Mato Grosso do Sul, Brazil. Rev. Bras. Entomol. 61:25-42.

URSO-GUIMARÃES, M.V. \& SCARELI-SANTOS, C. 2006. Galls and Gall makers in plants from the Pé-de-Gigante Cerrado Reserve, Santa Rita do Passa Quatro, SP, Brazil. Braz. J. Biol. 66:357-369.

URSO-GUIMARÃES, M.V., SCARELI-SANTOS, C. \& BONIFÁCIO-SILVA, A.C. 2003. Occurrence and characterization of entomogen galls in plants from natural vegetation areas in Delfinópolis, MG, Brazil. Braz. J. Biol. 63:705-715.

VIEIRA, L.G., NOGUEIRA, R.M., COSTA, E.C., CARVALHO-FERNANDES, S.P. \& SILVA, J.S. 2018. Insect galls in Rupestrian field and Cerrado stricto sensu vegetation in Caetité, Bahia, Brazil. Biota Neotrop. 18:e20170402 (last access on 20/12/2020).

Received: 08/01/2021 Revised: 09/06/2021 Accepted: 11/06/2021 Published online: 19/07/2021 